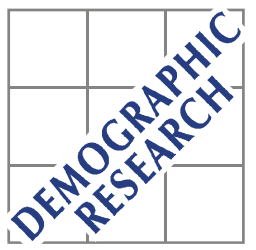

Demographic Research a free, expedited, online journal of peer-reviewed research and commentary in the population sciences published by the Max Planck Institute for Demographic Research Konrad-Zuse Str. 1, D-18057 Rostock · GERMANY www.demographic-research.org

DEMOGRAPHIC RESEARCH

VOLUME 8, ARTICLE 5, PAGES 107-150

PUBLISHED 12 March 2003

www.demographic-research.org/Volumes/Vol8/5/

DOI: $10.4054 /$ DemRes.2003.8.5

Descriptive Findings

\title{
Pathways to Stepfamily Formation in Europe: Results from the FFS
}

\author{
Alexia Prskawetz \\ Andres Vikat \\ Dimiter Philipov \\ Henriette Engelhardt
}

(C) 2003 Max-Planck-Gesellschaft. 


\section{Table of Contents}

$\begin{array}{lll}1 & \text { Introduction } & 108\end{array}$

2 Data and method $\quad 110$

3 Results 114

$\begin{array}{lll}3.1 & \text { Partnerships } & 115\end{array}$

$\begin{array}{lll}3.1 .1 & \text { First partnership } & 115\end{array}$

$\begin{array}{lll}3.1 .2 & \text { Second partnership } & 118\end{array}$

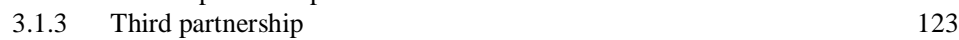

$\begin{array}{lll}3.1 .4 & \text { Summary } & 123\end{array}$

$3.2 \quad$ Childbearing 124

3.2.1 Pre-union children at first union formation 124

3.2.2 Pre-union children at second union formation 126

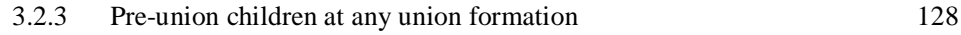

$\begin{array}{lll}3.2 .4 & \text { Summary } & 130\end{array}$

3.3 Change over time (birth cohorts) 135

4 Discussion 138

5 Acknowledgement 139

$\begin{array}{ll}\text { Notes } & 140\end{array}$

$\begin{array}{ll}\text { References } & 141\end{array}$

Appendix Graphical represenation of data from 144

Table 4 
Descriptive Findings

\title{
Pathways to Stepfamily Formation in Europe: Results from the FFS
}

\author{
Alexia Prskawetz ${ }^{1}$ \\ Andres Vikat ${ }^{2}$ \\ Dimiter Philipov ${ }^{3}$ \\ Henriette Engelhardt ${ }^{4}$
}

\begin{abstract}
Increasing proportions of couples are making childbearing decisions in stepfamilies but there has been no general comparative picture across European countries on stepfamily formation. The present paper aims to fill this gap and provides a comparison of European countries using macro-level indicators that describe union formation and dissolution and childbearing. We use the individual-level data files (standard recode files) of Fertility and Family Surveys from 19 European countries. Our results highlight the different pathways to a stepfamily in Europe, and show that in most European countries a considerable proportion of women form a stepfamily in childbearing ages, which needs to be considered in studies of fertility.
\end{abstract}

1 Max Planck Institute for Demographic Research, Konrad-Zuse-Str. 1, D-18057 Rostock, Germany. Email: fuernkranz@demogr.mpg.de

2 Max Planck Institute for Demographic Research, Konrad-Zuse-Str. 1, D-18057 Rostock, Germany. Email: vikat@demogr.mpg.de

3 Max Planck Institute for Demographic Research, Konrad-Zuse-Str. 1, D-18057 Rostock, Germany. Email: philipov@demogr.mpg.de

${ }^{4}$ Institute for Demography, Austrian Academy of Sciences, Prinz-Eugen-Str. 8, A-1040 Vienna, Austria. Email: henriette.engelhardt@ oeaw.ac.at 


\section{Introduction}

Changing family structures together with greater instability of marriages in most industrialized countries have changed the content of the notion of a stepfamily. Premarital childbearing and consensual unions are no longer an exception to families in the traditional sense, and childbearing is not restricted to one marital or consensual union (Kiernan 1999a, 1999b). This is of importance in relation to the concept of completed fertility over one's life course, since union disruption and formation of higher-order unions typically occur during one's reproductive years. To take into account these changes in family structures, the term stepfamily that was formerly restricted to marriages only, needs to be extended to include consensual unions involving a child of only one partner. This definition of stepfamilies takes into account the fact that an increasing proportion of higher-order unions are consensual unions.

A demographic study of stepfamily fertility integrates research on higher-order unions with the research on higher-order parity progression. While the increasing prevalence of higher-order unions is a characteristic of modern European societies, there has been a considerable decline in higher-order parity progression that in parts of Europe has resulted in 'lowest low' fertility (Kohler et al. 2002). Hence, it is of importance to understand the consequences of these opposite trends for European societies.

Recently, a stream of empirical demographic research on stepfamily fertility in various countries (Toulemon \& Lapierre-Adamcyk 1995, Thomson 1997, Toulemon 1997, 2001, Vikat et al. 1999, Buber \& Prskawetz 2000, Thomson, Hoem, and Godecker 2000, Thomson \& Godecker 2000, Henz 2002, and Thomson et al. 2002) has highlighted the importance of stepfamily fertility as an important research topic. Several studies have demonstrated the union commitment effect on fertility, that is, a birth risk is elevated if a couple does not have shared children (Vikat et al. 1999, Buber \& Prskawetz 2000, Thomson et al. 2002), which is one of the driving forces of fertility in unions where either partner already has children from a previous union. In addition to the union commitment effect, the first child to a couple may also be motivated by the parenthood effect, that is the desire of the childless partner to become a parent.

However, there has been no general comparative picture across European countries on stepfamily formation. The present paper aims to fill this gap and provides a comparison of European countries with respect to union formation and dissolution and childbearing. Similar to the country studies mentioned above we use individual level data. However, we apply those data for calculating macro-level indicators that describe cumulative experience of certain cohorts, whereas the mentioned country studies contain individual level event-history analyses. We also demonstrate the possibilities that an international effort like the Fertility and Family Surveys in the Countries of the 
ECE Region (FFS) provides to answer these questions. In this respect, our study proceeds in the spirit of the paper by Billari et al. (2001) who use information from different life domains for a cross-European comparison of home leaving, and Andersson \& Philipov (2002) who provide a broader comparison across FFS countries, including some indicators relevant for stepfamily formation.

Several comparisons of fertility and household formation patterns between European countries have been presented in the literature. Starting from the study by Lesthaeghe and van de Kaa (1986) and van de Kaa (1987) many of these studies have used the framework of the second demographic transition. These include amongst others the studies by Haskey (1993) and Kiernan (1996,1999a) on partnership formation and cohabitation, the study by Coleman (1996) on fertility patterns and the study by Lesthaeghe and Moors (1996) on living arrangements among young adults. In North and West European countries, with Sweden and Denmark as forerunners, postponement of marriage and childbearing and increasing prevalence of consensual unions have been observed first. Southern Europe followed this demographic pattern with some time lag while in Eastern Europe this demographic change did not take place until the 1990s. However, in the former socialist countries the transition towards low fertility and postponement of marriage and childbearing proceeded at a much faster pace as in other European countries. Nevertheless, in discussions about the convergence of European demographic trends it has been emphasized that in spite of certain similarity in the aggregate-level trends, many differences in demographic behavior between countries are likely to persist (Coleman 1996).

In this study, we suggest a grouping of European countries by patterns of combined union and childbearing careers. In particular, it is important that we are able to base such a description on full-scale life course information on consensual unions, because indicators of formal marriage are decreasingly reflecting the underlying union dynamics. The objectives of this article are

- to study the diversity of stepfamily formation among selected European countries, and more precisely, to find out the share of women of selected cohorts who experience stepfamily formation at an age that leaves time for childbearing in the stepfamily;

- to study the different pathways in terms of women's union and childbearing careers that can lead to stepfamily formation;

- $\quad$ to group the studied European countries by the cohort incidence of stepfamily formation and by the patterning of union and childbearing careers that lead to it. 


\section{Data and method}

Our study is based on the 1990s round of the Fertility and Family Surveys (FFS) in Europe. We have used the individual-level data files (standard recode files) available at the Population Activities Unit of the UN Economic Commission for Europe (UN ECE PAU), including in our study all the countries for which the internationally comparable FFS data was available. These countries are Austria, Belgium (representing Flanders), the Czech Republic, Estonia (native population only, Note 1), Finland, France, East Germany, West Germany, Hungary, Italy, Latvia (data on native population used, Note 1), Lithuania, Norway, Poland, Portugal (only data on entry into first unions available), Slovenia, Spain, Sweden, and Switzerland.

Our approach in this article is to describe the outcomes of union and childbearing careers by certain age in a given birth cohort. The words union and partnership are used as synonyms, denoting a coresidential union of married or unmarried partners, as defined in the FFS questionnaires (UN ECE PAU). According to the definition used in the FFS, the start of a union is set equal to the time point when a couple moves together and similarly the end of a union is the date at which the couple moves apart. Our data do not allow to discriminate between unions formed with the same partner as in a previous union, thus some of the higher-order unions may be repeated unions with the same partner.

We count a child born to the respondent at any time before union formation as a pre-union child. In the case of a first union, a pre-union child is a child who was born to the respondent before her first union started. In the case of a second union, a pre-union child could be born before the first union, in the first union, or between the first and second union. By using such a definition we may overestimate the number of stepchildren, since the partner with whom the union is formed may be the biological father of a pre-union child. However, other criteria would also introduce some bias, because we only have information on the dates of childbirth, and union formation and dissolution. By considering only those children who are born twelve months before union formation as pre-union children, which was one of the alternative specification we experimented with, we certainly got lower numbers of pre-union children. However, the relative difference between countries in the percentage of women with pre-union children or partner's children did not change notably. We also considered the possibility of excluding children born between the first and second union from pre-second-union children. In this case it would not have influenced the results because such children make up less than three percent of the children born to our cohorts before age 35 . Hence, we kept our straightforward definition of pre-union children as outlined above.

We choose the cohort approach to ensure consistency between the different life course stages we use in the comparison between countries. We consider that the 
sequence of life course events is often pre-determined, e.g., only those who have dissolved their first union can enter a second union. Our intention is not, however, to study the intensities of transitions from one status to another, but to focus on the probabilities of certain experiences in a life course. Though we base our calculations on individual level data, we are interested in macro-level differences of the experience of specific life course events (cf. Billari et al. 2001).

Table 1: $\quad$ Year of FFS interviews and the range of included birth cohorts.

\begin{tabular}{llll}
\hline Country & Abbreviation & Year of interview & Birth cohorts included \\
\hline & & & \\
Norway & NOR & $1988-89$ & $1945 / 50 / 55 / 60 / 65 / 68$ \\
Finland & FIN & $1989-90$ & $1938-67$ \\
Poland & POL & 1991 & $1934-74$ \\
Belgium & BEL & $1991-92$ & $1951-70$ \\
Germany & GER & 1992 & $1952-72$ \\
Hungary & HUN & $1992-93$ & $1951-74$ \\
Sweden & SWE & $1992-93$ & $1949 / 54 / 59 / 64 / 69$ \\
France & FRA & 1994 & $1944-73$ \\
Estonia & EST & 1994 & $1924-73$ \\
Lithuania & LIT & $1994-95$ & $1944-77$ \\
Slovenia & SLO & $1994-95$ & $1949-80$ \\
Switzerland & SUI & $1994-95$ & $1944-74$ \\
Latvia & LAT & 1995 & $1945-77$ \\
Spain & SPA & 1995 & $1945-77$ \\
Austria & AUT & $1995-96$ & $1941-76$ \\
Italy & ITA & $1995-96$ & $1946-75$ \\
Portugal & POR & 1997 & $1947-82$ \\
Czech Republic & CZE & 1997 & $1952-82$ \\
\hline
\end{tabular}

Note: If surveys of women and men differed in time or cohort composition this table pertains to the survey on women.

We use data for the cohort born in 1952-1959 in our comparisons. The choice of this cohort was based on optimizing the following considerations: the age the respondents had reached by the FFS interview, the country variation in the timing of the FFS surveys, sufficient number of observations for statistical power, and a consistent reference in time. The youngest members of this cohort reached age 30 in 1989, so we have complete observations for this cohort in almost all countries by that age, and we 
observe most part of the cohort until age 35 (Table 1, Figure 1). For a description of change over time, the indicators were also calculated for three smaller cohorts, born in 1952-1955, 1956-1959, and 1960-1964, respectively. For the youngest cohort, the upper age limit for the experience of an event needed to be restricted to age 30 because of right-censoring at the interview.

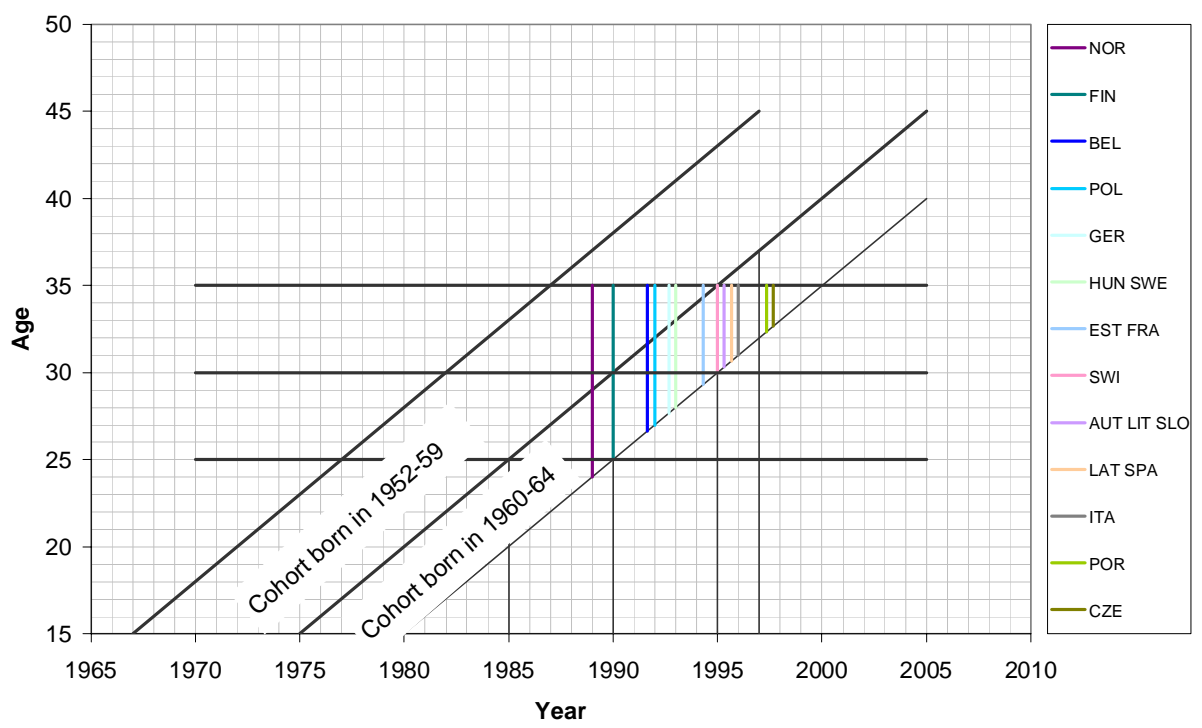

Note: The colored vertical lines represent the time when the FFS fieldwork was conducted in each country

Figure 1: The cohort-age range covered for each country in our study.

Since our data imposes truncation of observation at age 35, we are not able to consider the large number of stepfamilies formed after that age (Mazuy and Toulemon 2001). Considering that our focus is on combined histories of union formation and childbearing (i.e. stepfamilies where children could be born), this limitation is less harmful because it concerns only those years of the reproductive age span when fertility is declining. Nevertheless, due to the truncation, our indicators underestimate the proportion of women who form a stepfamily at reproductive age. 
The countries involved in our study had used samples that covered all birth cohorts within a specified range of years, with the exception of Sweden and Norway where the samples focused on certain years of birth (Table 1). To compare with the cohort 19521959, we used data on cohorts born in 1950, 1955, and 1960 from Norway, and on cohorts born in 1949, 1954, and 1959 from Sweden. All the calculations were made both for men and women, but we present the indicators for women only since answers on the number of pre-union children of men are often unreliable (Rendall et al. 1999, Buber and Prskawetz 2000).

In our calculations, we specified certain life course experiences as non-repeatable events and estimated survivor functions based on survival probabilities in single-year age-groups, using the Kaplan-Meier estimator in Stata software (StataCorp. 2001). For the comparative analysis of results we selected cutpoints at ages 20,25, 30 and 35; for presentation, we chose cutpoints that best described the event in question.

To describe the contribution of the processes of union formation and dissolution in the route to stepfamilies we use percentages of women in a cohort who have formed or dissolved a partnership of certain order by certain age. We also calculate union progression ratios that are defined similarly to the parity progression ratios used in fertility research. For instance, the union progression ratio from first to second union gives the number of second unions in relation to the number of first unions experienced by the specific cohort under consideration. Alternatively, we use a dissolution-based union progression ratio which gives the number of second unions in relation to the number of dissolutions of first unions experienced by the specific cohort under consideration. To gain a better understanding of the difficulty to form a stepfamily we also consider a union progression ratio that is restricted to women that have dissolved the first union and have children.

To describe the prevalence of stepfamilies, we define life events in terms of entering a union when there are pre-union children: (1) entry into a union when the woman already has pre-union children (regardless whether the man has pre-union children), and (2) entry into a union when either the woman or the man has pre-union children. We calculate both these events for (a) entry into any union as well as separately for (b) lifetime first and (c) second unions (very few unions of third and higher order were observed in the data). To have some idea on whether the pre-union children could have been conceived with the same partner with whom the union was later formed, we also calculated one of these indicators (entry into first union when the respondent already has pre-union children) by considering only those pre-union children that were born more than twelve months before the union started. 


\section{Results}

We present our results in four steps. As the first step, we start with a cross-country comparison of union formation and dissolution that can be understood as a measure of the potential for stepfamilies. We calculate the percentage of women (out of the initial cohort of women born in 1952 to 1959) who have entered their first, second and third partnership by certain age. Alternatively, we also calculate a union progression ratio that gives the proportion of those who form a second union among those who have formed at least one union. Similarly, we calculate the percentage of women who have experienced dissolution of the first and second partnership up to selected ages for the initial cohort of women born in 1952 to 1959 and alternatively for women who have formed a first and a second union. Since the number of children born in the first union and the probability of entering a second union after the first dissolves may depend on the type of union (cohabitation versus marriage), we also present the percentage of first unions that were cohabitation throughout. The potential of stepfamilies can then be associated with the prevalence of any union dissolution and the formation of any higher order union. By distinguishing union formation and dissolution by age of the respondent we aim to gain more insight whether, and in which countries, early partnership formation is associated with higher prevalence of union dissolution and higher order union formation.

We describe the entry into first partnership along the two dimensions of the quantum and the tempo of entering a first partnership. We think of the quantum as the proportion of all women in a cohort who ever enter a partnership within reproductive ages and use the percentage of women having entered a first partnership by age 35 as an approximate measure. The tempo is presented by the proportion of a cohort who had entered first partnership by age 20 .

In the second step we discuss childbearing histories in relation to union formation histories. We present the experience of union formation when having pre-union children both as the percentage of all those who enter the first or the second union and as the percentage of the entire cohort. Since the pattern of differences between countries varied whether we considered pre-union children at first or at second union formation we summarized the results on pre-union children by considering all unions, including the rare (by age 35) third and higher order unions.

By introducing information on the children of the male partner of the female respondent, we move to the third step. We measure the percentages of first and second unions and all unions regardless of order where either the respondent or her partner had children at union formation. Because of lacking information on partner's children, these indicators are not computed for Belgium, Estonia, Norway, and Sweden. 
We conclude the presentation of our results in the fourth step by comparing the indicators across the following birth cohorts: 1952-1955, 1956-1959 and 1960-1964. These comparisons will help to highlight any change over time in the pattern of stepfamily formation. Based on our findings we then propose a typology of countries that reflects different pathways to stepfamilies.

To make the country comparison across the various indicators as well as across cohorts easier we proceed from a grouping of countries based on geographical location and social system: Northern Europe (Finland, Norway, Sweden), Western Europe (Austria, Belgium, France, West Germany, Switzerland), Southern Europe (Italy, Portugal, Spain), and former socialist countries (Czech Republic, East Germany, Estonia, Hungary, Latvia, Lithuania, Poland, Slovenia - note that our data pertains to the time before the social and economic transition in those countries). We present our results in bar charts where we either order the countries within these groups by the studied indicator (Figures 2, 3, 4, 7, and 8) or present them in an overall order (Figures 5 and 11).

\subsection{Partnerships}

\subsubsection{First partnership}

In the North and West European countries, the percentage of the initial cohort of women who had entered their first partnership by age 35 (Figure 2) ranged from $93 \%$ (France and Switzerland) to 96\% (Belgium). West Germany was an exception with only $87 \%$. Within this group of countries there was a clear difference in the tempo of entering the first partnership. While in Sweden, Austria and France about 35\% to 40\% of all women had entered their first partnership by age 20, these numbers ranged between 26\% and 29\% in Finland, Norway, Belgium and West Germany. The lowest tempo of entering a first union could be observed in Switzerland with only $15 \%$ of the initial cohort having entered a first union by age 20 .

In the southern European countries of Italy and Spain women entered their first partnership at later ages. While a catch up effect of partnership formation was observed in Spain with about $94 \%$ of all women having entered first partnership by age 35, the later start translated also into a lower quantum of first partnerships in the case of Italy. Portugal did not follow this southern European pattern of first partnership formation: 
the tempo and quantum of first partnership formation in Portugal was among the highest observed in our set of countries.

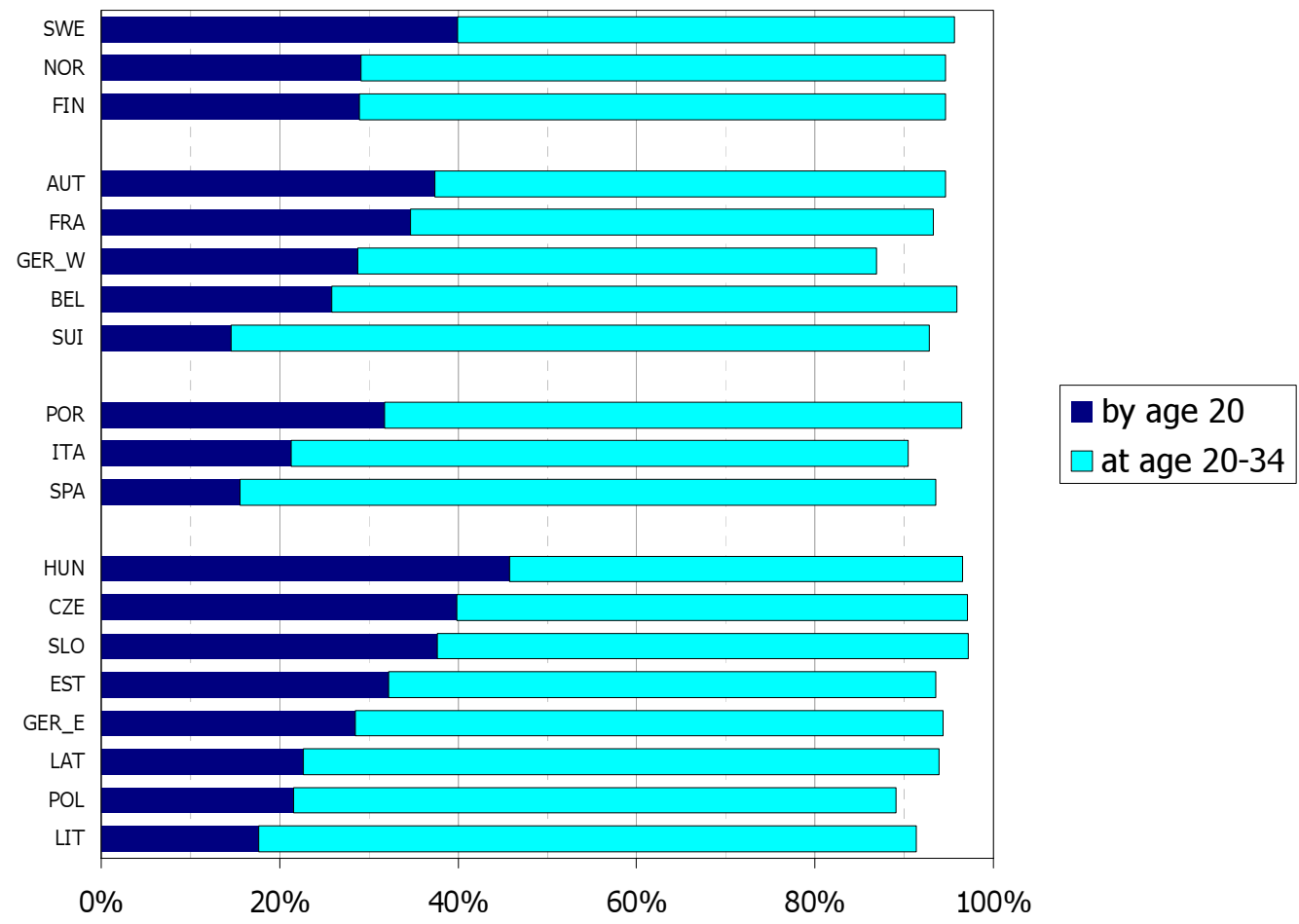

Figure 2: $\quad$ Percentage of women who have entered their first union by age 20 and by age 35, birth cohort 1952-1959.

Within the former socialist countries we could distinguish three groups. In Lithuania and Poland the tempo and quantum of first partnerships were the lowest. About one fifth of the initial cohort had entered a first partnership by age 20 and about $90 \%$ by age 35. In Hungary, the Czech Republic and Slovenia women had entered their first partnership earlier, and by age 35 they reached the highest percentages of those who had entered a partnership (from 96\% to 97\%) among the countries involved in our study. Hungarian women entered their first partnership the earliest, $46 \%$ of the cohort 
by age 20 . Estonia, Latvia, and East Germany lie in between with values close to those of the West European countries.

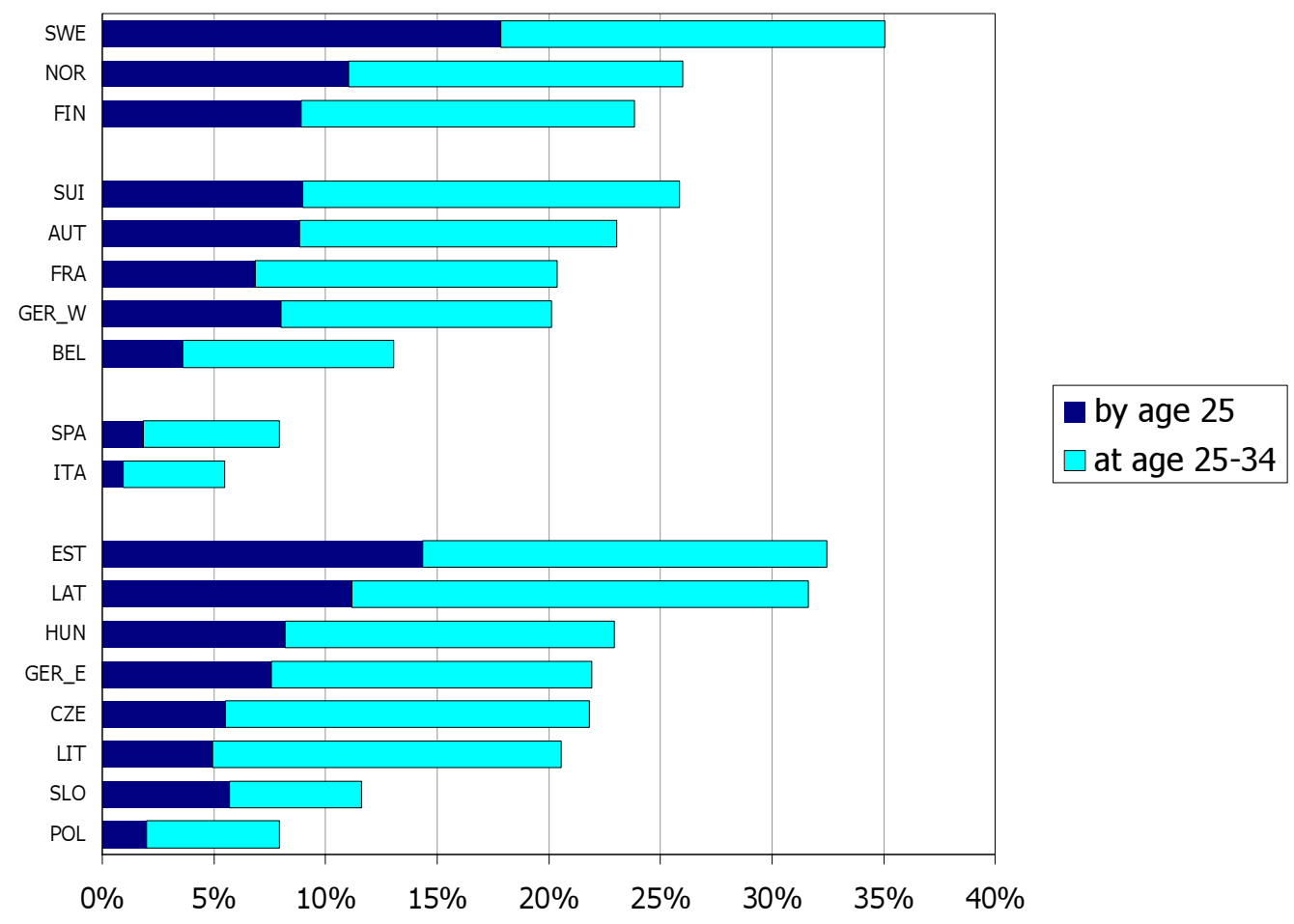

Figure 3: $\quad$ Percentage of women who have dissolved their first union by age 25 and by age 35, birth cohort 1952-1959.

North European countries have the highest share of women who had experienced dissolution of a first union, at any of the measured age cutpoints (Figure 3). Sweden clearly stood out with already $18 \%$ of all women having experienced a first dissolution by age 25 and $35 \%$ by age 35 . The dissolution of first partnerships was less prevalent in countries of Western Europe, at lower ages in particular (except Switzerland which stays close to Norway and Finland). In Austria and France where entry into first partnership at lower ages was comparable to Sweden, only about $9 \%$ and $7 \%$, respectively, of the initial cohort experienced a first dissolution by age 25 . However, up 
to age 35, already about $20 \%$ of the initial cohort of women experienced first dissolution in most West European countries, except Belgium. In Belgium where entry into first partnership was late but the proportions of women who experienced first partnership by age 35 were high, the experience of dissolution was the lowest in the studied West European countries, $4 \%$ by age 25 and $13 \%$ by age 35 . In South European countries we observed the lowest share of women with a union dissolution experience, $6 \%$ by age 35 in Italy and $8 \%$ in Spain (Note 2). Later entry and lower prevalence of first partnerships in those countries are likely to have contributed to this.

Among the former socialist countries, the picture of union dissolution was somewhat different from the one on entering the partnership. In Latvia and Estonia, about one third of all women in the initial cohort had experienced a first dissolution by age 35, which is clearly higher than in the other studied former socialist countries and at about the same level as in Sweden. While Lithuania and Poland were both characterized by relatively late entry into partnership and a relatively low percentage of women who had entered a partnership by age 35, a much larger percentage of Lithuanian women had gone through a union dissolution (21\%) than in Poland (8\%). In the Czech Republic, East Germany and Hungary we observed percentages of women with dissolution experience that are in the size order of those observed in West European countries, while in Slovenia where the indicators of entry into first partnership were close to the mentioned three countries, the percentage of women with dissolution experience was almost as low as in Poland.

\subsubsection{Second partnership}

As stepfamilies are mostly associated with higher-order unions we are interested whether the experience of a first dissolution acts as a predictor for the formation of second unions. Our results confirm such a conjecture. We observed the highest percentage of women experiencing a second union by age 35 in Sweden where 27\% of the initial cohort had entered a second union by age 35 (Figure 4), followed by Estonia (24\%) and Latvia (19\%). Norway, Switzerland, Finland and Austria - countries where the first dissolution experience was high - had also a relatively high percentage of the initial cohort that experience a second union (15\% to $17 \%$ ). In the remaining West European countries these numbers were lower and they were lowest for Belgium (Belgium also had the lowest share of first dissolution experience among the studied West European countries) where only $7 \%$ of all women experienced a second union by age 35. The prevalence of second partnerships was almost negligible in Italy, Spain and Poland with at most $4 \%$ of all women having experienced a second union by age 35 (in Spain). Again, these are the countries where we observed the lowest experience of first 
dissolution. In the Czech Republic, East Germany and Hungary the experience of second partnerships was in the order of West European countries. In Lithuania, a comparable dissolution rate like in the Western countries, however, did not translate into corresponding numbers of the prevalence of second partnerships. Only about $8 \%$ of the initial cohort experienced a second union by age 35 though almost $21 \%$ of all women experienced a first dissolution by age 35. On the other hand, in Slovenia and Poland a lower dissolution rate of first partnerships translated into lower prevalence of second union formation.

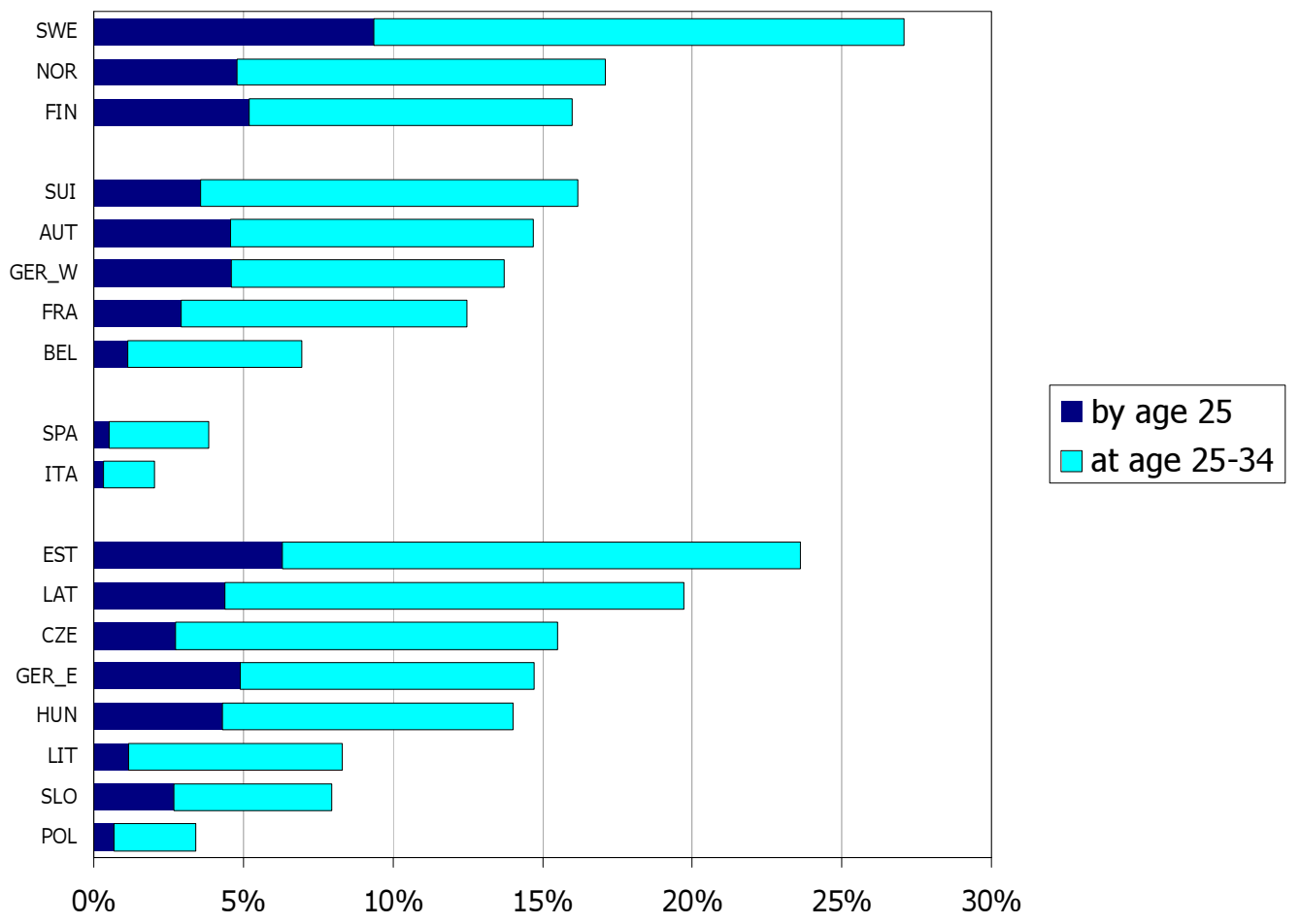

Figure 4: $\quad$ Percentage of women who have entered a second union by age 25 and by age 35, birth cohort 1952-1959. 
If we group the countries according to second partnerships experienced by age 35 we arrive at a different classification as the one we started off (Figure 5). Sweden is clearly the country with the highest prevalence of second unions and is followed by Estonia and Latvia. South European countries (Italy and Spain) and Poland have the lowest prevalence of second unions. In between, the remaining North, West European countries and former socialist countries form two groups.

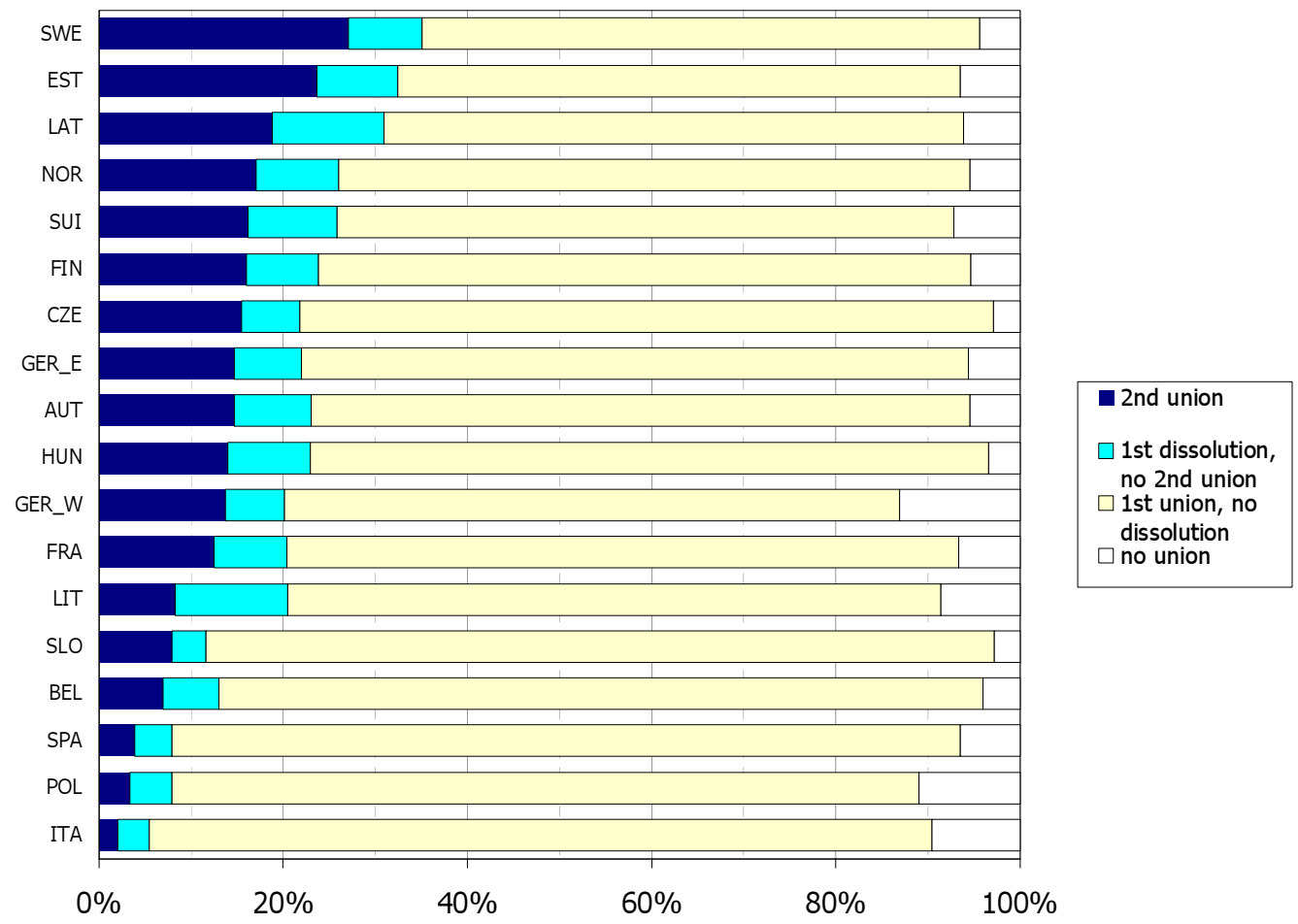

Figure 5: $\quad$ Cumulative union history experience of women born in 1952-1959. 
Table 2: $\quad$ Indicators of progression from first to second union by age 35 for the 1952-1959 birth cohort.

\begin{tabular}{|c|c|c|c|c|}
\hline & & $\begin{array}{l}\text { Proportion of women } \\
\text { who enter second } \\
\text { union among those } \\
\text { who enter the first } \\
\text { union }\end{array}$ & $\begin{array}{l}\text { Proportion of women } \\
\text { who enter second } \\
\text { union among those } \\
\text { who dissolve the first } \\
\text { union }\end{array}$ & $\begin{array}{l}\text { Proportion of women } \\
\text { who enter second } \\
\text { union among those } \\
\text { who dissolved the } \\
\text { first union and have } \\
\text { children }^{\star}\end{array}$ \\
\hline \multirow[t]{3}{*}{ North } & FIN & 0.17 & 0.67 & 0.55 \\
\hline & NOR & 0.18 & 0.66 & 0.61 \\
\hline & SWE & 0.28 & 0.77 & 0.65 \\
\hline \multirow[t]{5}{*}{ West } & AUT & 0.16 & 0.64 & 0.52 \\
\hline & BEL & 0.07 & 0.53 & 0.49 \\
\hline & FRA & 0.13 & 0.61 & 0.51 \\
\hline & GER_W & 0.16 & 0.68 & 0.57 \\
\hline & SUI & 0.17 & 0.63 & 0.46 \\
\hline \multirow[t]{2}{*}{ South } & ITA & 0.02 & 0.37 & 0.26 \\
\hline & SPA & 0.04 & 0.48 & 0.39 \\
\hline \multirow{8}{*}{$\begin{array}{l}\text { Former } \\
\text { socialist } \\
\text { countries }\end{array}$} & CZE & 0.16 & 0.71 & 0.65 \\
\hline & GER_E & 0.16 & 0.67 & 0.65 \\
\hline & HUN & 0.15 & 0.61 & 0.55 \\
\hline & POL & 0.04 & 0.43 & 0.39 \\
\hline & SLO & 0.08 & 0.69 & 0.59 \\
\hline & EST & 0.25 & 0.73 & 0.71 \\
\hline & LAT & 0.21 & 0.62 & 0.60 \\
\hline & LIT & 0.09 & 0.40 & 0.39 \\
\hline
\end{tabular}

* This is a progression ratio from status 'dissolved first union, parity 1+' to status 'in second union, parity 1+'. The combined status 'dissolved first union, parity $1+$ ' can be attained either when a woman with children separates, or when a separated woman has her first child.

Viewed from a different angle, we may also consider a union progression ratio (Table 2) that gives the proportion of those who form a second union among those who have formed at least one union (first column, Table 2), or alternatively relate the former number to the share of the initial cohort who has experienced a first dissolution (second column, Table 2). Applying the first definition of the union progression ratio does not change the general picture of second union experience. However, restricting the denominator to only those who have experienced a first dissolution slightly changes the 
country classification. Sweden still stands out with $77 \%$ of all first dissolutions being followed by a second union by age 35. West and East Germany, the Czech Republic, Slovenia and Estonia come next with $68 \%$ to $73 \%$ of first dissolutions being followed by a second union. The classification of the remaining countries is not influenced by this alternative measure of union progression. The progression ratio to second union for those women who have dissolved the first union and have children (column 3, Table 2) allows us to assess whether the probabilities of second union formation differ between women with and without children. In all countries, the proportion of women who enter a second union is lower among separated mothers (column 3, Table 2) than among all separated women (column 2, Table 2), which tells us that a woman's probability of entering a second union is lower when she has children.

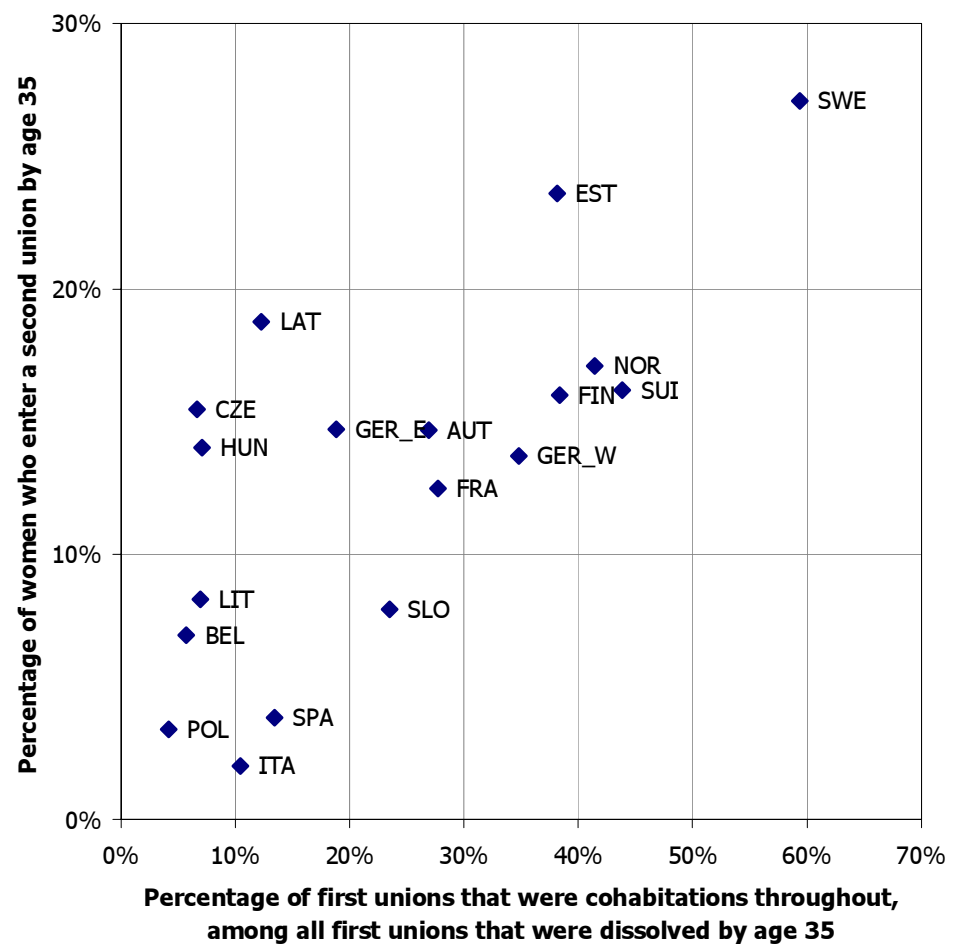

Figure 6: $\quad$ Plot of countries by the percentage of dissolved first unions that were cohabitation throughout and the percentage of women who enter a second union by age 35, birth cohort 1952-1959. 
The percentage of first unions that were cohabitation throughout shows some positive correlation with the experience of second unions (Figure 6). On the background of this overall pattern we note that in Latvia, Hungary, and the Czech Republic a medium level of second-union experience was reached while only very few first unions were cohabitation throughout in those countries.

\subsubsection{Third partnership}

The share of women who experienced a third partnership by age 35 exceeded the 5\% mark only in the case of Sweden. For the remaining North and West European countries about $1 \%$ to $3 \%$ of the initial cohort of women experienced a third union with Belgium being again an outlier with only $0.6 \%$. Similarly low and almost negligible numbers as in Belgium were observed in Italy, Spain and Poland. In the former socialist countries only $1 \%$ to $2 \%$ of women had experienced a third union by age 35 . The pattern across countries of the prevalence of third unions therefore follows closely the pattern we already observed in case of second partnerships.

\subsubsection{Summary}

Women in the North European countries experience more partnerships. In West European countries (except Belgium) and most of the former socialist countries (except Lithuania, Poland and Slovenia) we observed a lower number of unions, but the share of women who enter a second union is still relevant for the potential of stepfamily formation (Figure 5). Among those countries, Latvia and Estonia stand out for their high first dissolution rates and high prevalence of second unions. The lowest number of higher-order unions, and a negligible potential for stepfamilies in this respect, was observed in South European countries, and in Lithuania, Poland, Slovenia, and Belgium. 


\subsection{Childbearing}

\subsubsection{Pre-union children at first union formation}

The highest proportion of women who had children when they formed their first union, $32 \%$, was observed in East Germany (Figure 7). Slovenia and Austria followed next with $13 \%$. In all the other studied countries the share of women with at least one child at first union formation was below $10 \%$. In Belgium, Italy and Spain this share was the lowest, below $3 \%$.

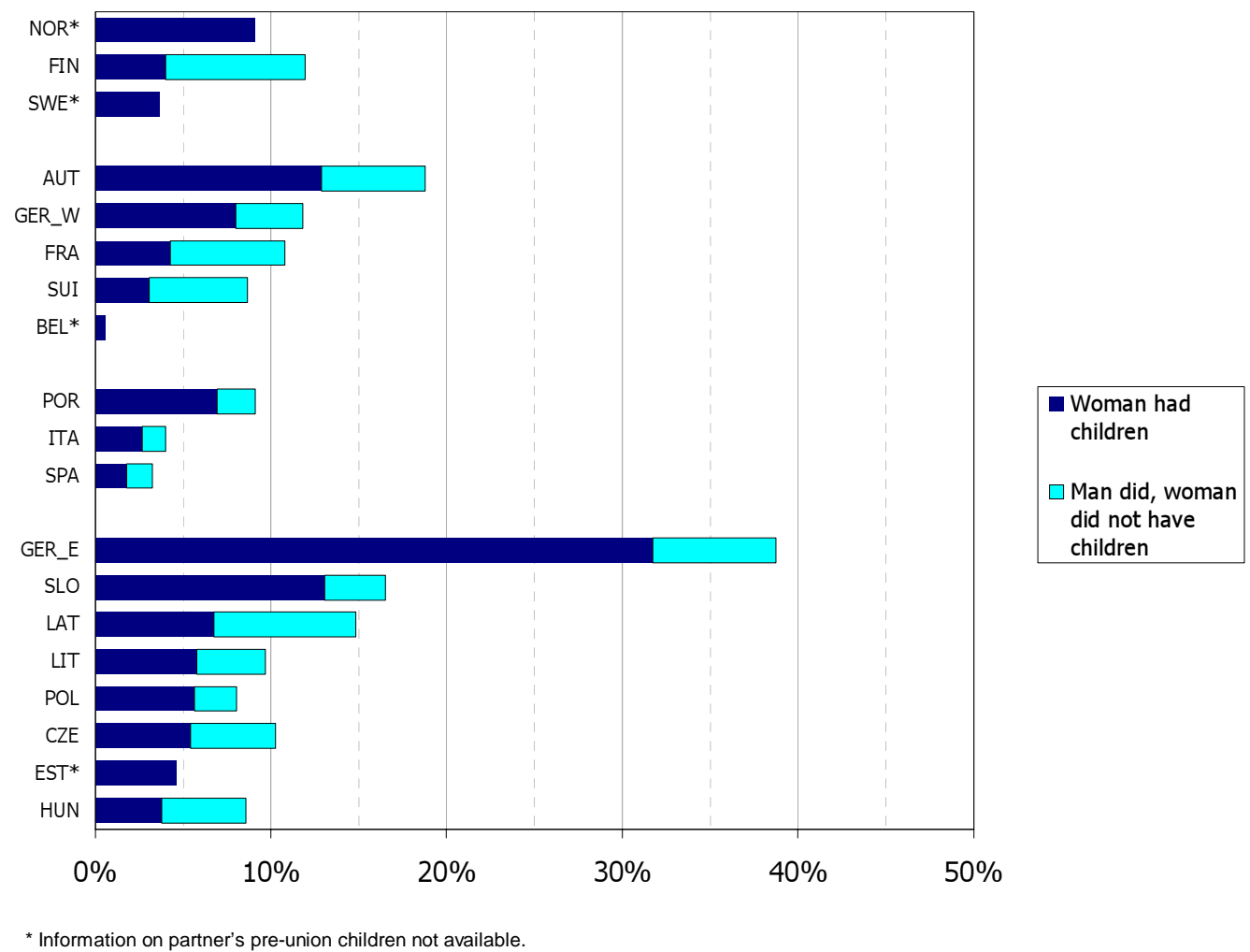

Figure 7: Percentage of women's first unions with own and partner's pre-union children at union formation. First unions up to age 35, birth cohort 1952-1959. 
The extraordinarily high percentage of first unions with pre-union children in East Germany warranted us to take a closer look at the timing of the birth of the pre-union children in relation to the starting time of the first union. About half of the children born before the first union were born within twelve months before the union, and this share does not show much variation among the countries with a sizable proportion of prefirst-union children. It is indeed likely that a considerable proportion of the children born within the twelve-month period that immediately preceded union formation are biological children of both partners who form the union (for East Germany, see Huinink and Konietzka 2000). However, even after we restrict the definition of pre-union children to children who were born more than twelve months before union, East Germany still stands out and the relative differences between countries in the percentage of women with pre-union children or partner's children do not change notably.

For most countries (the exceptions were Belgium, Estonia, Norway, and Sweden) it was possible to consider also the contribution of pre-union children of the male partner, that is, the first unions of the woman where the man did and the woman did not have pre-union children. The unions where both of them had pre-union children were already captured by considering the pre-union children of the woman, in which case we did not differentiate by whether her partner also had pre-union children or not. In Finland, France, Switzerland, Latvia, and Hungary, the share of first unions with preunion children more than doubled when we considered children of both partners (Figure 7). It has to be borne in mind, though, that the union order is that of the woman's, and it can be assumed that many of the men who have children enter their second or higher order union with the respondent. When we consider also the man's pre-union children in the overall comparison, Finland and Latvia move up to the countries with a relatively high share of pre-first-union children. The lowest shares of pre-first-union children are in Italy and Spain, and Poland, Lithuania and Hungary in the socialist countries. 


\subsubsection{Pre-union children at second union formation}

The whole group of the former socialist countries had higher proportion of women who had children at their second union formation (Figure 8). It ranged from 65\% in Slovenia to $85 \%$ in Latvia. Among the other countries, the variation did not follow our country grouping in any systematic manner. The proportion of women with children at second union formation ranged from $42 \%$ in Sweden to $61 \%$ in Spain, with Switzerland as an outlier with $29 \%$.

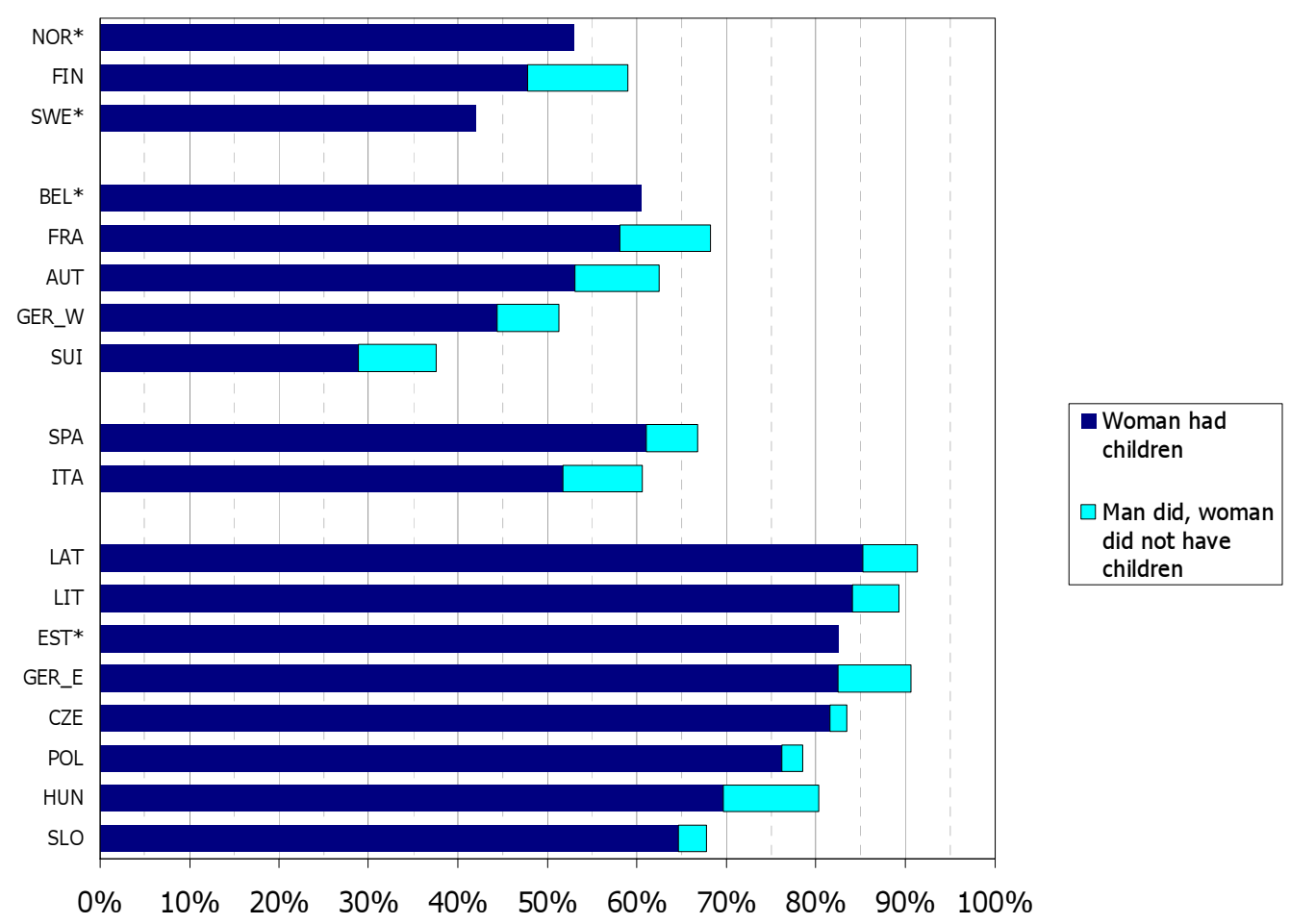

* Information on partner's pre-union children not available.

Figure 8: $\quad$ Percentage of women's second unions with own and partner's pre-union children at union formation. Second unions up to age 35, birth cohort 1952-1959. 
Considering the contribution of man's pre-union children, that is, second unions of the woman where the man did and the woman did not have children at union formation, did not essentially alter the picture (Figure 8). In Finland and Switzerland, considering those unions increased the proportion of woman's second unions starting with preunion children from $48 \%$ to $59 \%$, and from $29 \%$ to $38 \%$, respectively. In other countries that contribution was smaller.

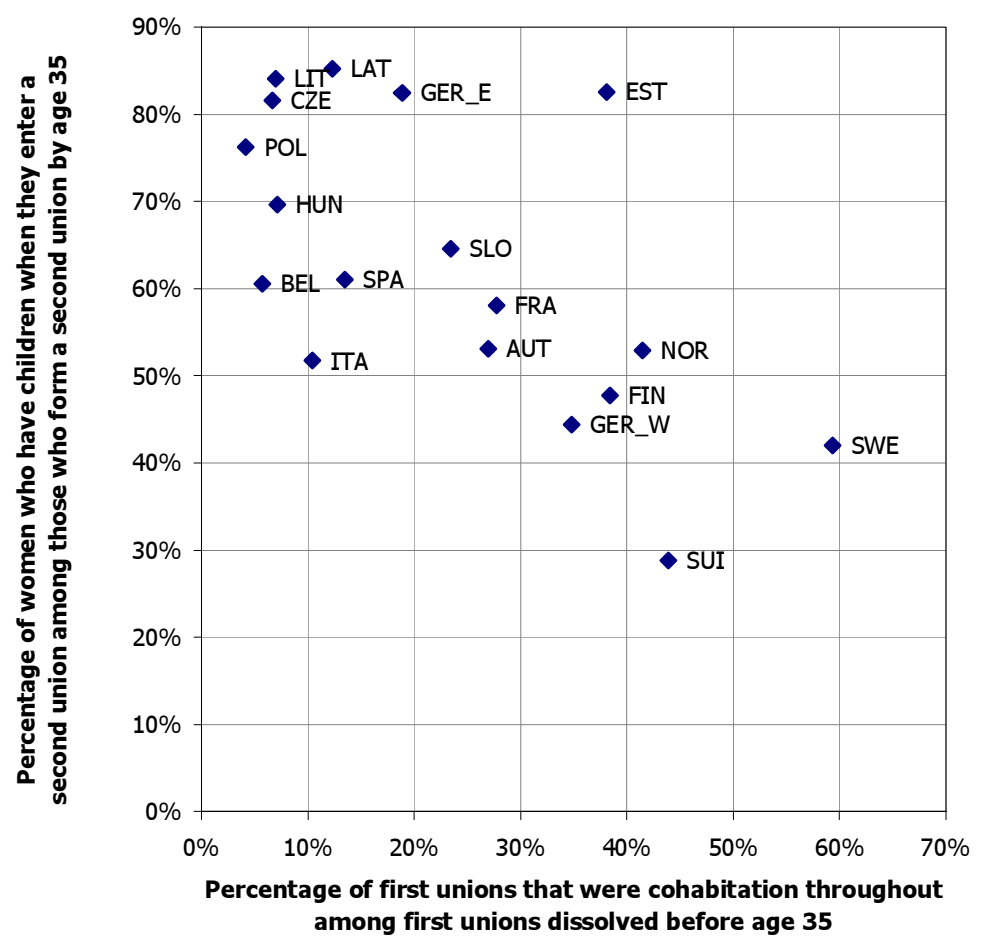

Figure 9: $\quad$ Plot of countries by the percentage of dissolved first unions that were cohabitations throughout and the percentage of women's second unions with pre-union children at union formation, birth cohort 1952-1959.

The type of the first dissolved union is generally associated with the share of women who have children when they enter a second union (Figure 9). The higher the percentage of first unions that were cohabitations throughout the lower the percentage 
of women who have children when they enter a second union. Estonia and Switzerland deviate from this pattern. In Estonia, a relatively high share of non-marital unions is accompanied with a very high share $(83 \%)$ of women with children at entry into second union, while in Switzerland where non-marital unions make up about the same share of dissolved first unions, only $29 \%$ of women have children when they enter a second union. Interestingly, the catholic countries do not form a pattern.

\subsubsection{Pre-union children at any union formation}

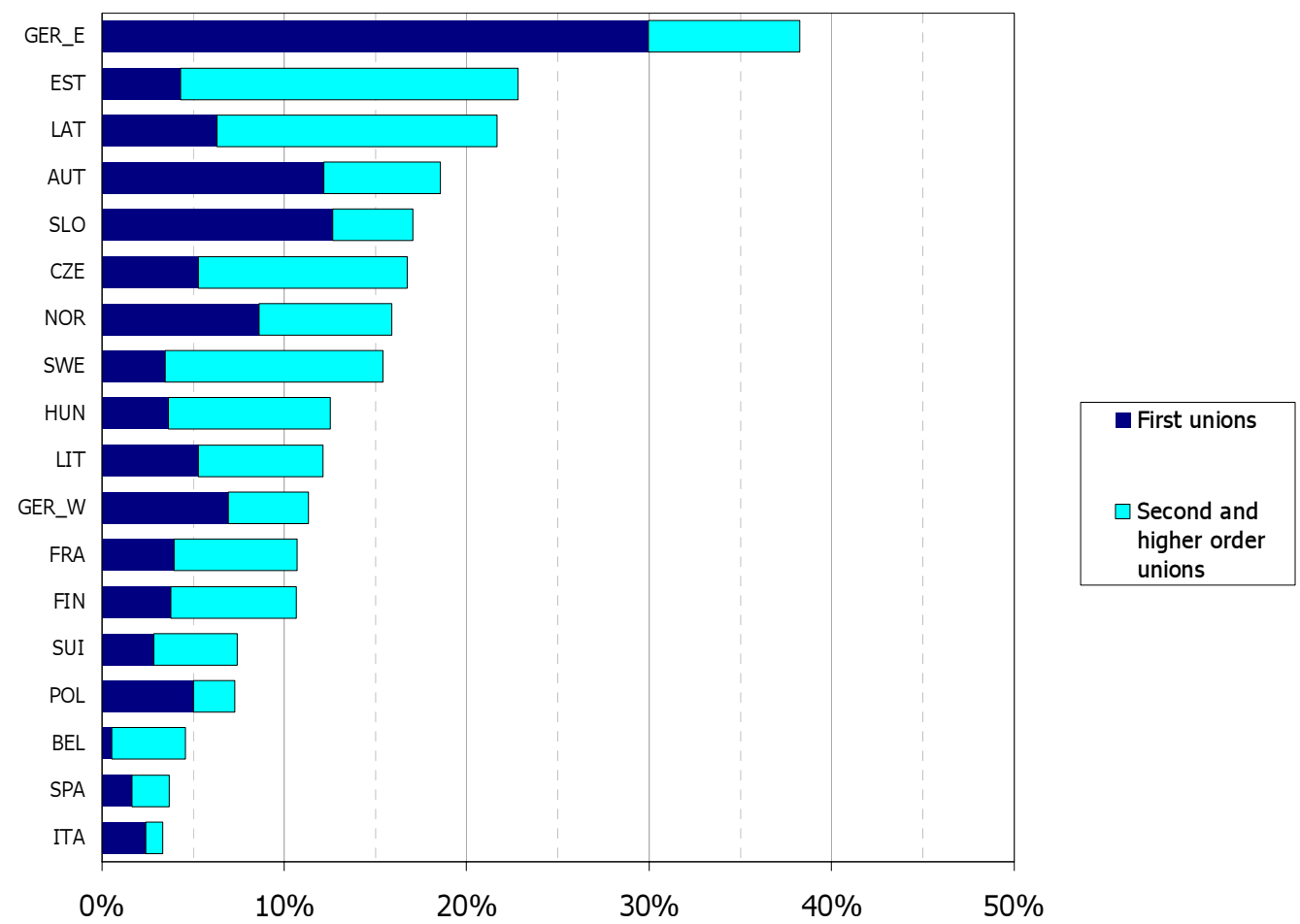

Figure 10: Experience of any union formation by age 35 where the woman already had own pre-union children and the contribution of first unions to this, birth cohort 1952-1959. 
The experience of entering any union with pre-union children was highest in East Germany, 38\% (Figure 10). The bulk of these cases were first unions with prior children. A high share of first unions with pre-union children also contributes to the relatively high share of overall union experience with pre-union children in Austria, $19 \%$.

The experience of union formation with prior children is also high in Estonia and Latvia, 23\% and 20\%, respectively, but the large majority of those cases are women who enter a second union having children from their first union. In the other former socialist countries except Poland, and in Norway and Sweden, the share of women who experience union formation with own pre-union children is within the range from $12 \%$ to $17 \%$. 


\subsubsection{Summary}

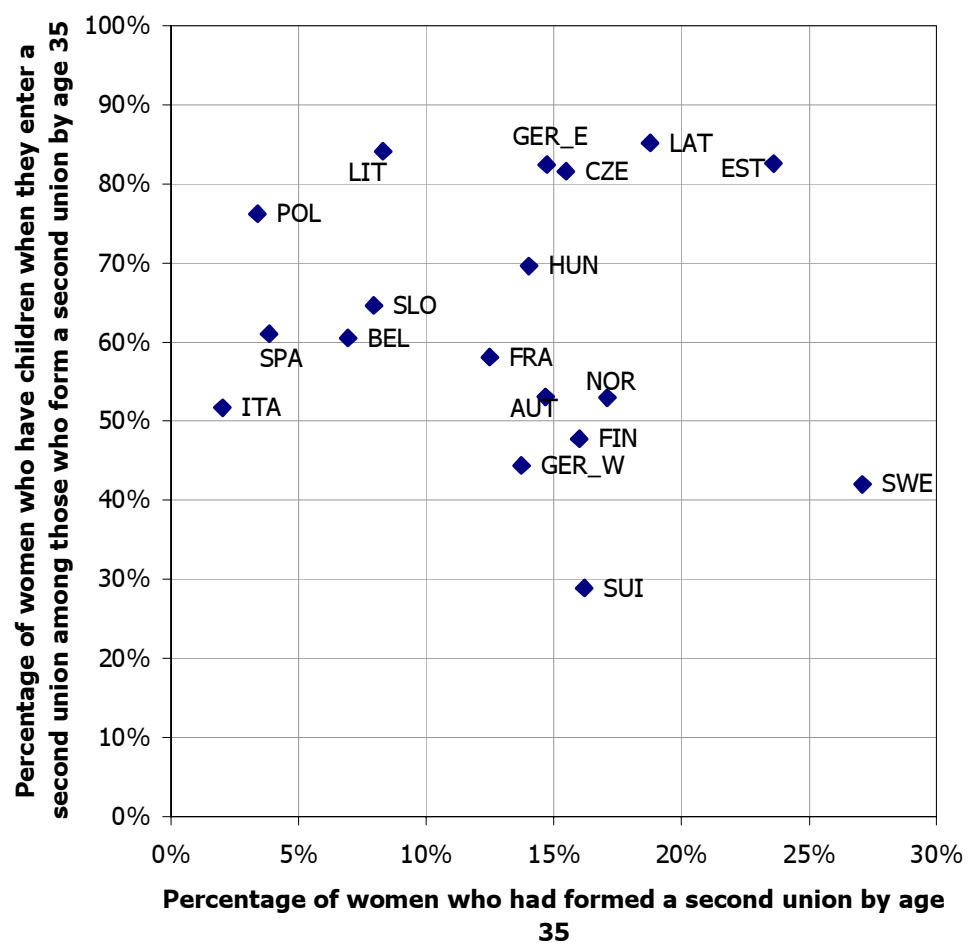

Figure 11: Plot of countries by the percentage of women with pre-union children at second union formation of all second unions formed before age 35, and the percentage of women who enter a second union by age 35, birth cohort 1952-1959.

Altogether we could distinguish six patterns of combined union and childbearing careers. One dividing line was that between the two social systems that prevailed in Europe during the reproductive ages of our cohorts. All the former socialist countries were characterized by a universal prevalence of pre-union children - more than $70 \%$ of women who enter a second union already had a child (Figure 11). However, there was 
considerable variation in dissolution and repartnering rates between those countries, and we can distinguish three groups among them. The highest experience of a stepfamily before age 35 of all countries was reached in Estonia and Latvia where the high prevalence of children in first unions was accompanied with relatively high rates of separation and repartnering (first pattern). The Czech Republic, East Germany and Hungary constitute an intermediate group (second pattern), while Poland and Lithuania (third pattern) form a group with few second unions and few stepfamilies.

In all the studied Western countries women were less likely to have had children in the eventually dissolved first unions, compared to the former socialist countries of central and eastern Europe. With respect to second union experience, we could also distinguish three groups among the Western countries. Sweden represents a group of its own (fourth pattern) with no children in most dissolved first unions while dissolution as well as repartnering are frequent. West European countries (except Belgium) together with Finland and Norway also displayed a relatively low percentage of women with children among those who entered a second union, but the second-union experience in those countries is far lower than in Sweden (fifth pattern). Southern Europe and Belgium constitute a group of very low prevalence of second unions and they have the lowest prevalence of stepfamilies among all the studied countries (sixth pattern). 
Table 3: $\quad$ Data presented in the map in Figure 12.

\begin{tabular}{|c|c|c|}
\hline Region & Country & $\begin{array}{l}\text { Percentage of women from the } \\
\text { entire cohort who had } \\
\text { experienced a second union } \\
\text { formation by age } 35 \text { where the } \\
\text { woman already had own pre-union } \\
\text { children, birth cohort } 1952-1959\end{array}$ \\
\hline \multirow[t]{3}{*}{ North } & FIN & 7.6 \\
\hline & NOR & 9.1 \\
\hline & SWE & 11.4 \\
\hline \multirow[t]{5}{*}{ West } & AUT & 7.8 \\
\hline & BEL & 4.2 \\
\hline & FRA & 7.3 \\
\hline & GER_W & 6.1 \\
\hline & SUI & 4.7 \\
\hline \multirow[t]{2}{*}{ South } & ITA & 1.1 \\
\hline & SPA & 2.4 \\
\hline \multirow{8}{*}{$\begin{array}{l}\text { Former } \\
\text { socialist } \\
\text { countries }\end{array}$} & CZE & 12.6 \\
\hline & GER_E & 12.1 \\
\hline & HUN & 9.8 \\
\hline & POL & 2.6 \\
\hline & SLO & 5.1 \\
\hline & EST & 19.5 \\
\hline & LAT & 16.8 \\
\hline & LIT & 7.0 \\
\hline
\end{tabular}


Figure 12: Map of studied countries by the experience of a second union formation by age 35 where the woman already had own pre-union children, birth cohort 1952-1959 (data from Table 3).

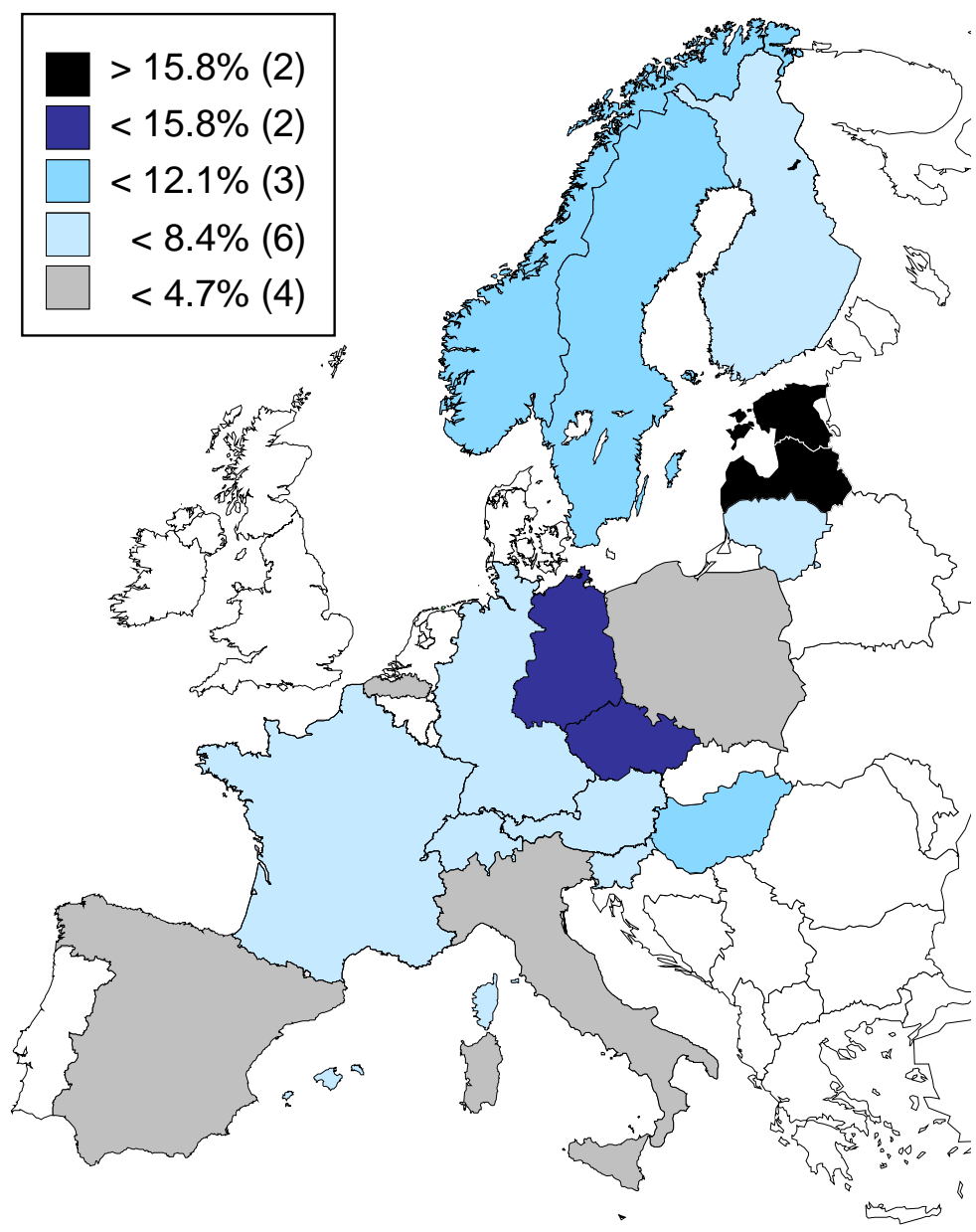

Footnote: The cutpoints for the differently colored country groups were obtained by dividing the distance between the maximum and minimum value into five equal intervals. 
The six patterns of combined union and childbearing histories described above result in different levels of stepfamily experience. We study this by a combined measure of the experience of a second union with pre-union children by age 35 (Table 3, Figure 12). By this measure we could observe four groups of countries. First, every fifth Estonian woman of the 1952-1959 cohort entered a second union by age 35 while having children prior to that union, and that proportion was almost as high, 17\%, in Latvia (first pattern of combined union and childbearing careers). Second, the Czech Republic and East Germany came next with $13 \%$ and $12 \%$, respectively, and Sweden and Hungary also had a relatively high level of $11 \%$ and $10 \%$ (second and fourth pattern of combined union and childbearing careers). Third, in Finland, Norway, Austria, France, West Germany and Switzerland the percentage of the 1952-1959 cohort that entered a second union by age 35 while having children prior to that union ranged from $6 \%$ to $9 \%$ (fifth pattern of combined union and childbearing careers). This indicator is within the same range also in Lithuania, but unlike in the other countries at that level, Lithuanian women had only few second unions while many of those unions started with pre-union children (third pattern of combined union and childbearing careers). Fourth, the lowest experience of stepfamilies was observed in Poland (third pattern like in Lithuania, but with somewhat fewer second unions and somewhat fewer of them starting with preunion children), Belgium, Italy, and Spain (sixth pattern of combined union and childbearing careers). 


\subsection{Change over time (birth cohorts)}

Table 4: $\quad$ Percentage of women from the entire cohort who enter a second union, and percentage of women with pre-union children at second union formation of all second unions by age and birth cohort.

\begin{tabular}{|c|c|c|c|c|}
\hline & \multicolumn{2}{|c|}{ Experience by age 30} & \multicolumn{2}{|c|}{ Experience by age 35} \\
\hline & $\begin{array}{l}\text { Percentage of } \\
\text { women in the cohort } \\
\text { who entered a } \\
\text { second union by age } \\
30\end{array}$ & $\begin{array}{l}\text { Percentage of } \\
\text { women with pre- } \\
\text { union children at } \\
\text { second union } \\
\text { formation of all } \\
\text { second unions } \\
\text { formed before age } 30\end{array}$ & $\begin{array}{l}\text { Percentage of } \\
\text { women in the } \\
\text { cohort who } \\
\text { entered a } \\
\text { second union } \\
\text { by age } 35\end{array}$ & $\begin{array}{l}\text { Percentage of } \\
\text { women with } \\
\text { pre-union } \\
\text { children at } \\
\text { second union } \\
\text { formation of } \\
\text { all second } \\
\text { unions } \\
\text { formed } \\
\text { before age } 35\end{array}$ \\
\hline Birth cohort: & $1952-55 \quad 1956-59 \quad 1960-64$ & $1952-55 \quad 1956-59 \quad 1960-64$ & $1952-55 \quad 1956-59$ & $1952-55 \quad 1956-59$ \\
\hline
\end{tabular}

\begin{tabular}{lrrrrrrrrrr} 
Country & & & & & & & & & & \\
FIN & 8.7 & 13.2 & $\mathrm{a}$ & 46.2 & 34.6 & $\mathrm{a}$ & 14.0 & $\mathrm{a}$ & 52.8 & $\mathrm{a}$ \\
NOR & $6.6^{\mathrm{b}}$ & $12.9^{\mathrm{c}}$ & $\mathrm{a}$ & $67.5^{\mathrm{b}}$ & $48.3^{\mathrm{c}}$ & $\mathrm{a}$ & $11.0^{\mathrm{b}}$ & $\mathrm{a}$ & $71.1^{\mathrm{b}}$ & $\mathrm{a}$ \\
SWE & $14.7^{\mathrm{d}}$ & $19.1^{\mathrm{e}}$ & $27.7^{\mathrm{f}}$ & $56.2^{\mathrm{d}}$ & $41.5^{\mathrm{e}}$ & $27.1^{\mathrm{f}}$ & $20.6^{\mathrm{d}}$ & $26.7^{\mathrm{e}}$ & $56.1^{\mathrm{d}}$ & $44.9^{\mathrm{e}}$ \\
\hline AUT & 9.8 & 9.9 & 13.2 & 56.0 & 41.3 & 41.7 & 14.5 & 14.9 & 63.6 & 43.4 \\
BEL & 4.6 & 3.7 & 8.6 & 56.8 & 53.6 & 44.0 & 7.7 & 6.3 & 65.7 & 53.1 \\
FRA & 9.8 & 7.7 & 12.7 & 56.4 & 49.3 & 32.5 & 13.4 & 11.7 & 57.0 & 59.2 \\
GER_W & 9.5 & 10.4 & 12.0 & 34.8 & 22.5 & 47.4 & 12.6 & 14.8 & 46.5 & 44.0 \\
SUI & 8.9 & 10.4 & 14.0 & 34.3 & 16.7 & 22.6 & 15.2 & 17.2 & 37.2 & 21.9 \\
\hline ITA & 0.9 & 0.9 & 1.7 & 52.7 & 47.8 & 32.1 & 1.7 & 2.4 & 55.4 & 49.4 \\
SPA & 2.0 & 2.5 & 4.1 & 41.4 & 55.6 & 41.0 & 3.0 & 4.8 & 55.6 & 65.1 \\
\hline CZE & 8.8 & 10.0 & 12.5 & 60.9 & 94.2 & 59.7 & 14.9 & 15.9 & 63.4 & 93.0 \\
GER_E & 10.8 & 8.9 & 14.5 & 76.1 & 81.7 & 78.3 & 14.6 & 14.8 & 79.8 & 84.6 \\
HUN & 10.3 & 9.5 & 12.1 & 58.6 & 68.6 & 67.9 & 14.9 & 12.8 & 66.8 & 73.8 \\
POL & 1.8 & 1.7 & 1.7 & 63.7 & 50.3 & 80.0 & 3.3 & 3.7 & 80.0 & 73.4 \\
SLO & 6.8 & 5.6 & 5.9 & 57.6 & 63.8 & 69.7 & 7.8 & 8.2 & 60.1 & 69.5 \\
EST & 18.9 & 15.2 & 17.8 & 78.0 & 86.5 & 75.6 & 23.0 & 24.4 & 78.7 & 86.7 \\
LAT & 10.5 & 13.0 & 8.8 & 79.0 & 80.0 & 75.0 & 18.8 & 20.4 & 85.3 & 85.1 \\
LIT & 5.0 & 4.4 & 5.9 & 61.2 & 85.6 & 62.9 & 9.1 & 7.6 & 81.0 & 87.4 \\
\hline
\end{tabular}

${ }^{a}$ Cohort could not be observed because of an earlier time of the survey. ${ }^{b}$ Data from the 1950 birth cohort. ${ }^{c}$ Data from the 1955 birth cohort. ${ }^{d}$ Data from the 1949 birth cohort. ${ }^{e}$ Data from the 1954 birth cohort. ${ }^{\dagger}$ Data from the 1959 birth cohort. 
In Table 4, the prevalence of second unions starting with pre-union children is presented for three consecutive birth cohorts of 1952-1955, 1956-1959 and 19601964, by ages 30 and 35 (for a graphical representation see Appendix Figure A). We observe second partnerships that have been formed by age 30 for all three cohorts, while second partnerships by age 35 could be obtained for the first two cohorts only.

A comparison across the first two cohorts indicates that in North European countries the share of women who have formed a second partnership by age 30 has increased over time while the share of women with pre union children among those who formed a second union has decreased (for a graphical representation see Appendix Figure B). For West European countries there is not much variation across the cohorts in terms of the formation of second partnerships. However, we observe a trend towards a decrease of partnerships with pre-union children among those second partnerships and it is most pronounced in Austria, Belgium and Switzerland. For South European countries (Italy and Spain) and most of the former socialist countries there is again not much variation across cohorts in terms of second partnership formation. However, in Spain, and in most former socialist countries, the Czech Republic in particular, we observed an increase in women with children among those who entered their second partnership. 
Table 5: $\quad$ Percentage of women from the entire cohort who had experienced a second union formation by age 35 where the woman already had own pre-union children, birth cohorts 1952-1955 and 1956-1959.

\begin{tabular}{|c|c|c|c|}
\hline & & $\begin{array}{l}\text { Cohort born } \\
\text { in 1952-1955 }\end{array}$ & $\begin{array}{c}\text { Cohort born } \\
\text { in 1956-1959 }\end{array}$ \\
\hline \multirow[t]{3}{*}{ North } & FIN & 7.4 & 7.6 \\
\hline & NOR & 7.8 & 9.1 \\
\hline & SWE & 11.5 & 12.0 \\
\hline \multirow[t]{5}{*}{ West } & AUT & 9.2 & 6.4 \\
\hline & BEL & 5.0 & 3.3 \\
\hline & FRA & 7.7 & 6.9 \\
\hline & GER_W & 5.9 & 6.5 \\
\hline & SUI & 5.6 & 3.8 \\
\hline \multirow[t]{2}{*}{ South } & ITA & 0.9 & 1.2 \\
\hline & SPA & 1.7 & 3.1 \\
\hline Former & CZE & 9.5 & 14.8 \\
\hline socialist & GER_E & 11.6 & 12.5 \\
\hline \multirow[t]{6}{*}{ countries } & HUN & 9.9 & 9.5 \\
\hline & POL & 2.6 & 2.7 \\
\hline & SLO & 4.7 & 5.7 \\
\hline & EST & 18.1 & 21.1 \\
\hline & LAT & 16.0 & 17.4 \\
\hline & LIT & 7.3 & 6.7 \\
\hline
\end{tabular}

We may conclude that over cohorts, the relation between birth and union histories has become less closely related for North European and partly also for West European countries. In these countries, the experiences of a higher order union became more frequent while pre-union children at second union formation became less frequent. In most South European countries and the former socialist countries childbearing remained to be strongly connected to first unions. Across cohorts, there was a slight increase in the experiences of forming a second union with pre-union children in most studied countries (Table 5). However, in four out of the five West European countries, Austria, Belgium, France and Switzerland, there was a decrease. 


\section{Discussion}

A life history survey like the FFS is very useful in presenting the patterns of demographic life courses and comparing them across countries and cohorts. With very little variation, the definition of a coresidential partnership was comparable across the countries and that permitted us to compare the indicators combined from union and birth histories. However, also various problems emerged, like those of the differences in the time the surveys were taken, and the cohorts involved in the surveys. From the point of view of our study, it was also a shortcoming that children could not explicitly be linked to certain partnerships. It is possible that some of the pre-union children at first union formation are biological children of both partners. This is the reason why we had to stick to the description of the prevalence of stepfamilies mainly by referring to second partnerships (see Figure 12). Again, we may overestimate the share of women who enter their second partnership with pre-union children since part of these pre-union children may already be biological children of the partner with whom the second union was formed. However, the bias may be much less as compared to first partnerships. As the sequencing of demographic events (such as the birth of children and union formation) becomes more complex over time surveys need to be adjusted to capture these more complicated biographies and to obtain more clear cut results on questions like the prevalence of stepfamilies as considered in this paper.

In all the former socialist countries we observed that most of the women who formed a second union had children. This means that children were born also in a large proportion of eventually dissolved first unions. At least two known explanations to such pattern could be pointed out. First, in the socialist countries partners had a motivation to marry and have children relatively early, confirming to the prevailing norms (see, e.g., Wendt 1997) and motivated by various benefits given to families with children, housing in particular (Klinger 1991), and, second, once in a partnership, erratic contraceptive supplies and contraceptive nonuse contributed to the number of unintended births (David 1999). In Western countries, in Sweden in particular, a first union did not necessarily reach a level of mutual commitment where the partners consider having children. The cohorts observed in this study already carried the postponement of childbearing, a trend prevailing in Europe starting from the late 1960s. In addition, the factors that lead to the eventual breakdown of a first union may have contributed to the general instability of that union so that the partners did not want to have any children together. Our finding about the decreasing proportion of women in Western countries who have children when they enter a second union is consistent with the well documented trend of postponing childbearing, in that there are fewer unions with children among the eventually dissolved first unions. 
In addition to the above discussed distinction between countries of different social systems, our results also reflected differentials in second-union experience determined by first-union dissolution and repartnering. Sweden with its historical tradition of nonmarital cohabitation has been pointed out as a forerunner in many demographic trends, and the pattern of high prevalence of consensual unions, in particular the relatively high prevalence of those consensual unions that are not converted to marriage at any stage, and the high dissolution and repartnering rates showed up distinctly in our results too. Despite the fact that the dissolved first unions of Swedish women were among the least likely to have offspring, Sweden was still among the countries with high stepfamily experience. Among the former socialist countries, Estonia and Latvia had union formation and dissolution indicators pretty close to Sweden, and when accompanied with the childbearing context of the socialist system there, it resulted in the highest stepfamily experience among our observed countries.

Second-union experience in the former socialist countries of Central Europe (the Czech Republic, East Germany, and Hungary), in Western Europe and in Finland and Norway was pretty much the same, but the three former socialist countries had high stepfamily experience since most of the women in second unions had children from first unions. Notably, women in these three former socialist countries had the same stepfamily experience as in Sweden, though the underlying patterns of demographic behavior were largely different. Countries with the lowest prevalence of second unions - Lithuania, Poland, Italy, Spain, and Belgium - all share a relatively strong influence of the Catholic Church.

Our results highlight the different pathways to a stepfamily in Europe, and show that in most European countries a considerable proportion of women enter a stepfamily in childbearing ages, which needs to be considered in studies of fertility.

\section{Acknowledgement}

We wish to thank the Advisory Group of the FFS program of comparative research for its permission, granted under identification number 75, to use the FFS data on which this study is based. We also wish to thank Elizabeth Thomson, Laurent Toulemon, Kalev Katus and two anonymous referees for their comments and suggestions. 


\section{Notes}

1. Estonian data was available only for the native population. For Latvia we decided to use only data for ethnic Latvians to enhance comparability of these two populations whose behavioral patterns are close to each other. Almost a third of the population of Estonia and about a half in Latvia are of foreign origin. We know from previous research that the demographic behavior of the native-born and immigrant population differs in those countries (Bondarskaya 1994, Katus 1990, Vikat 1994).

2. The standard recode file for Portugal does not include information on partnership dissolution and on the formation of second or higher order partnerships. 


\section{References}

Andersson, G., Philipov, D. (2002). Life-table representations of family dynamics in Sweden, Hungary, and 14 other FFS countries: A project of descriptions of demographic behavior. Demographic Research [online] 7, 4. Available at http://www.demographic-research.org/volumes/vol7/4/7-4.pdf

Buber, I., Prskawetz, A. (2000). Fertility in second unions in Austria: Findings from the Austrian FFS. Demographic Research 3, 2. Available at http://www.demographic-research.org/Volumes/Vol3/2

Billari, F.C., Philipov, D., Baizan, P. (2001). Leaving home in Europe: The experience of cohorts born around 1960, International Journal of Population Geography 7: $339-356$.

Bondarskaya, G. (1994) Ethnic-territorial differences in marital fertility. In: Lutz, W., Scherbov, S., Volkov, A. (eds.). Demographic Trends and Patterns in the Soviet Union Before 1991. London \& New York: IIASA: 71-88.

Coleman, D. (1996). New patterns and trends in European fertility: International and sub-national comparisons. In: Coleman, D. (ed.). Europe's population in the 1990s. Oxford University Press: 1-61.

David, H.P. (ed.) (1999). From Abortion to Contraception: A Resource to Public Policies and Reproductive Behavior in Central and Eastern Europe from 1917 to the Present. Westport, Connecticut/ London: Greenwood Press.

Haskey, J.C. (1993). Formation and dissolution of unions in the different countries of Europe. In: Blum, A., Rallu, J.L. (eds.). European Population. Vol. 2. Demographic Dynamics. Paris: John Libbey Eurotext: 211-229.

Henz, U. (2002). Childbirth in East and West German stepfamilies: Estimated probabilities from hazard rate models. Demogrphic Research [online] 7, 6. Available at http://www.demographic-research.org/Volumes/Vol7/6/7-6.pdf.

Huinink, J., Konietzka, D. (2000). Leaving parental home in the Federal Republic of Germany and the GDR, paper presented at the Workshop on 'Leaving Home - A European Focus', Max Planck Institute for Demographic Research, September 2000. Available at http://www.demogr.mpg.de/Papers/workshops/000906_paper11.pdf

Katus, K. (1990) Demographic trends in Estonia throughout the centuries. Yearbook of Population Research in Finland XXVIII, Helsinki: Väestöliitto: 50-66 
Kiernan, K. (1996). Partnership behaviour in Europe: Recent trends and Issues. In: Coleman D (ed.). Europe's population in the 1990s. Oxford University Press: 62-91.

Kiernan, K. (1999a). Cohabitation inWestern Europe. Population Trends, 96: 26-32.

Kiernan, K. (1999b). Childbearing outside marriage in Western Europe. Population Trends, 98: 11-22.

Klinger, A. (1991). Les politiques familiales en Europe de l'Est. Population, 46, 3, 511526

Kohler, H.-P., Billari, F.C., Ortega, J.A. (2002). The emergence of lowest-low fertility in Europe during the 1990s. Population and Development Review, 28(4): 641-680.

Lesthaeghe, R., Moors, G. (1996) Living Arrangements, Socio-Economic Position, and Values Among Young Adults: A Pattern Description for France, West Germany, Belgium, and the Netherlands, 1990, In: Coleman, D. (ed.). Europe's population in the 1990s. Oxford University Press: 163-221.

Lesthaeghe, R., van de Kaa, D.J. (1986). Twee Demografische Transities? (Two Demographic Transitions?). In: van de Kaa, D.J., Lesthaeghe, R. (eds.). Bevolkning: Groei en Krimp (Population: Growth and Decline). Deventer: van Loghem Slaterus: 19-68.

Mazuy M., Toulemon L. (2001) Étude de l'histoire familiale : premiers résultats de l'enquête en ménages. Ined, coll. Dossiers et recherches, $n^{\circ} 93,83$ pages.

Rendall, M.S., Clarke, L., Peters, H.E., Ranjit, N., Verropoulou, G. (1999). Incomplete reporting of men's fertility in the United States and Britain: a research note. Demography 36, 1: 135-144.

StataCorp (2001). Stata Statistical Software: Release 7.0. College Station, TX: Stata Corporation.

Thomson, E., Godecker, A.L. (2000). Intended and unintended stepfamily fertility. Paper presented at the annual meeting of the Population Association of America, Los Angeles, March 23-25, 2000.

Thomson, E., Hoem, J.M., Godecker, A.L. (2000). Partnership and parenthood: Unobserved heterogeneity in stepfamily fertility. Paper at the American Sociological Association meeting, Washington, DC, August 12-16, 2000. 
Thomson, E., Hoem, J.M., Vikat, A., Prskawetz, A., Buber, I., Toulemon, L., Henz, U., Godecker, A.L., Kantorova, V. (2002). Childbearing in stepfamilies: How parity matters. In: Klijzing, E., Corijn,M. (eds.). Fertility and Partnership in Europe: Findings and Lessons from Comparative Research. Volume II. Geneva/New York: United Nations: forthcoming.

Thomson, E. (1997). Her, His and Their Children: Influences on Couple Childbearing Decisions. National Survey of Families and Households Working Paper \#76, Center for Demography and Ecology, University of Wisconsin-Madison, Madison, WI, 1997.

Toulemon, L. (1997). The Fertility of Step-families: The Impact of Childbearing before the Current Union. Paper presented at the Annual Meeting of the Population Association of America, Washington, DC, 1997.

Toulemon, L., Lapierre-Adamcyk, É. (1995). Demographic Patterns of Motherhood and Fatherhood in France. Paper presented at the IUSSP Anthropology and Demography Committee Seminar on Fertility and the Male Life Cycle in the Era of Fertility Decline, Zacarecas, November 1995.

Toulemon, L. (2001). Men's fertility and family size as compared to women's, XXIVth meeting of the IUSSP, Brazil, 2001.

UN ECE PAU. FFS model questionnaire for women. Available at http://www.unece.org/ead/pau/ffs/design22.htm

Van de Kaa, D. (1987). Europe's Second Demographic Transition. Population Bulletin 41,1

Vikat, A. (1994). Family Formation in Estonia. Publications of the Finnish Demographic Society, 15. Helsinki: Finnish Demographic Society.

Vikat, A., Hoem, J.M., Thomson, E. (1999). Stepfamily fertility in contemporary Sweden: The impact of childbearing before the current union. Population Studies 53: 211-225.

Wendt, H. (1997). The former German Democratic Republic: The standardized family. In: Kaufmann, F.X., Kuijsten, A., Schulze, H.J., Strohmeier, K.P. (eds.). Family Life and Family Policies in Europe: Structures and Trends in the 1980s. Oxford: Clarendon. 


\section{Appendix: Graphical represenation of data from Table 4}

Figure A: $\quad$ Plot of countries by the percentage of women with pre-union children at second union formation of all second unions formed before age $30 /$ by age 35, and the percentage of women who enter a second union by age 30 / by age 35, birth cohort 1952-1955, 1956-59, 1960-64.

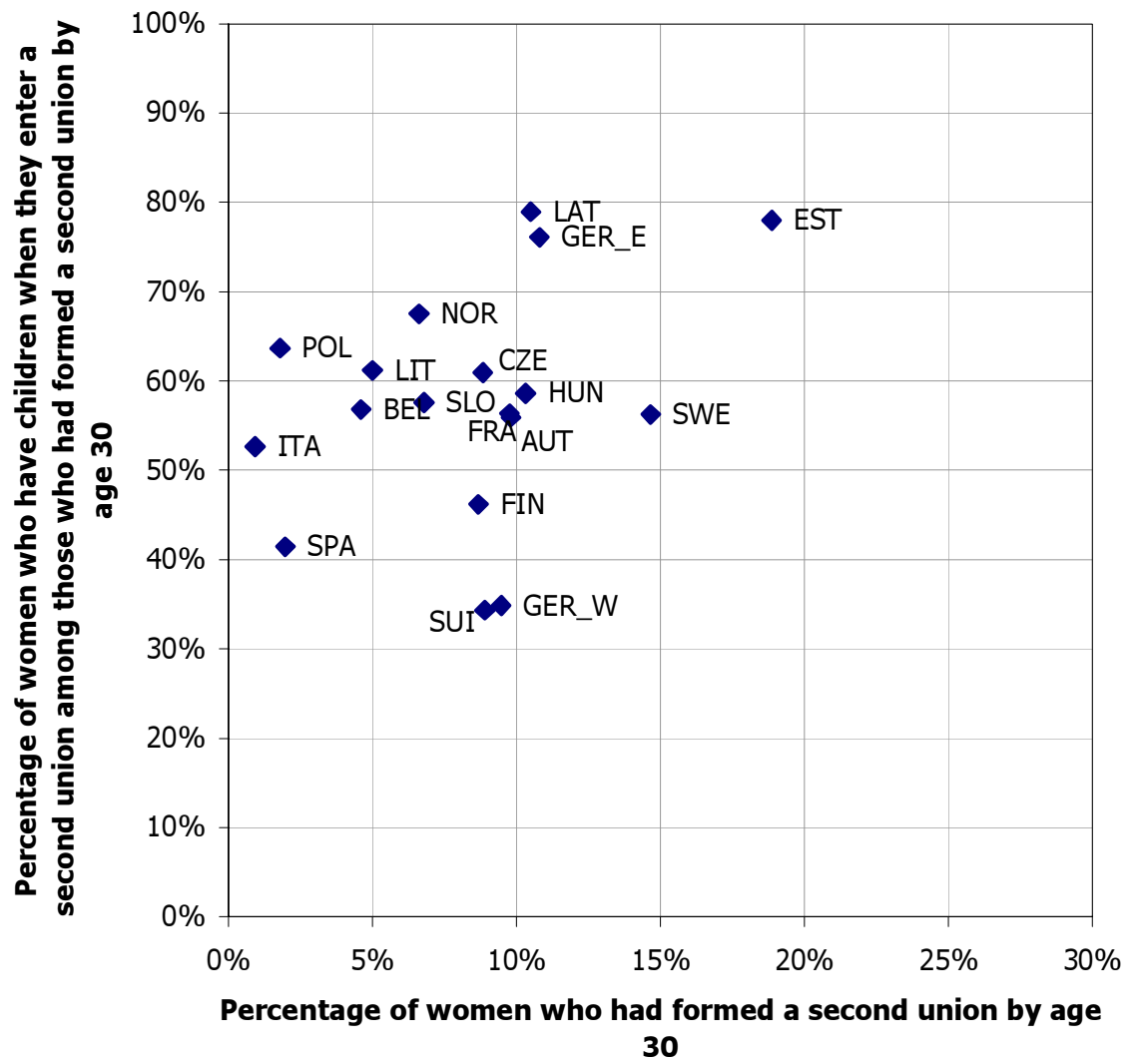

A1: $\quad$ Cohort born in 1952-1955, by age 30 


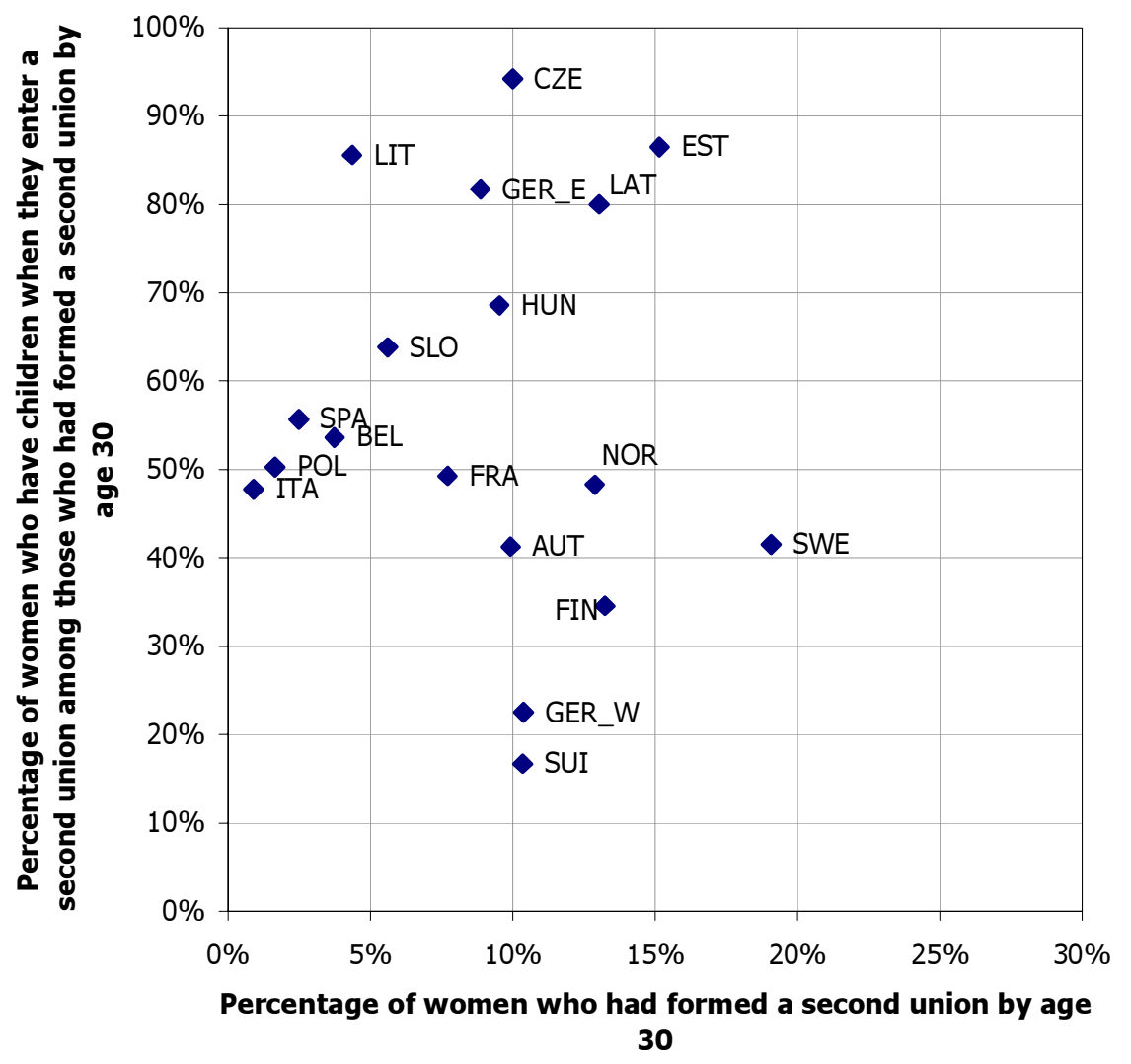

A2: $\quad$ Cohort born in 1956-1959, by age 30 


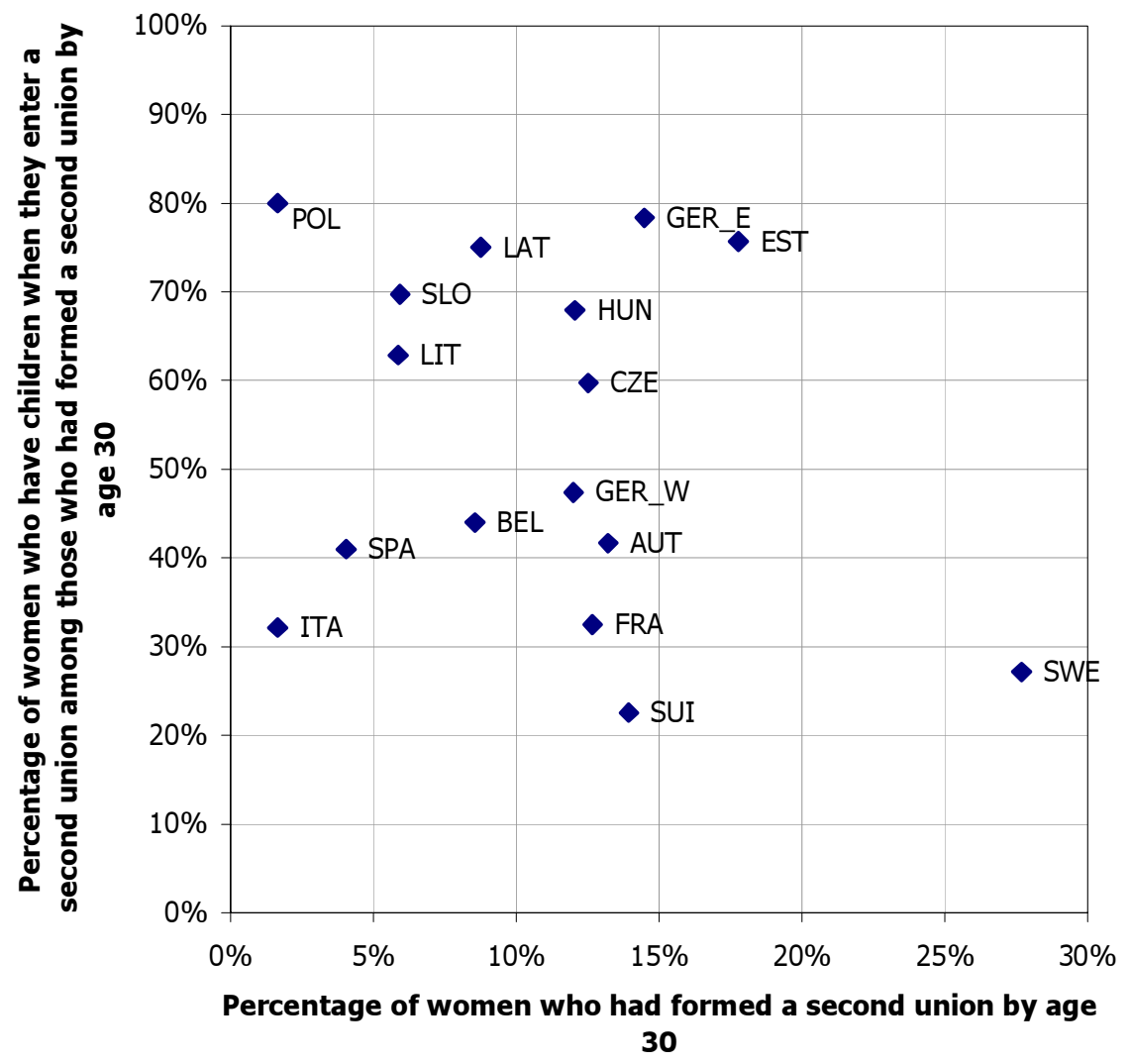

A3: $\quad$ Cohort born in 1960-1964, by age 30 


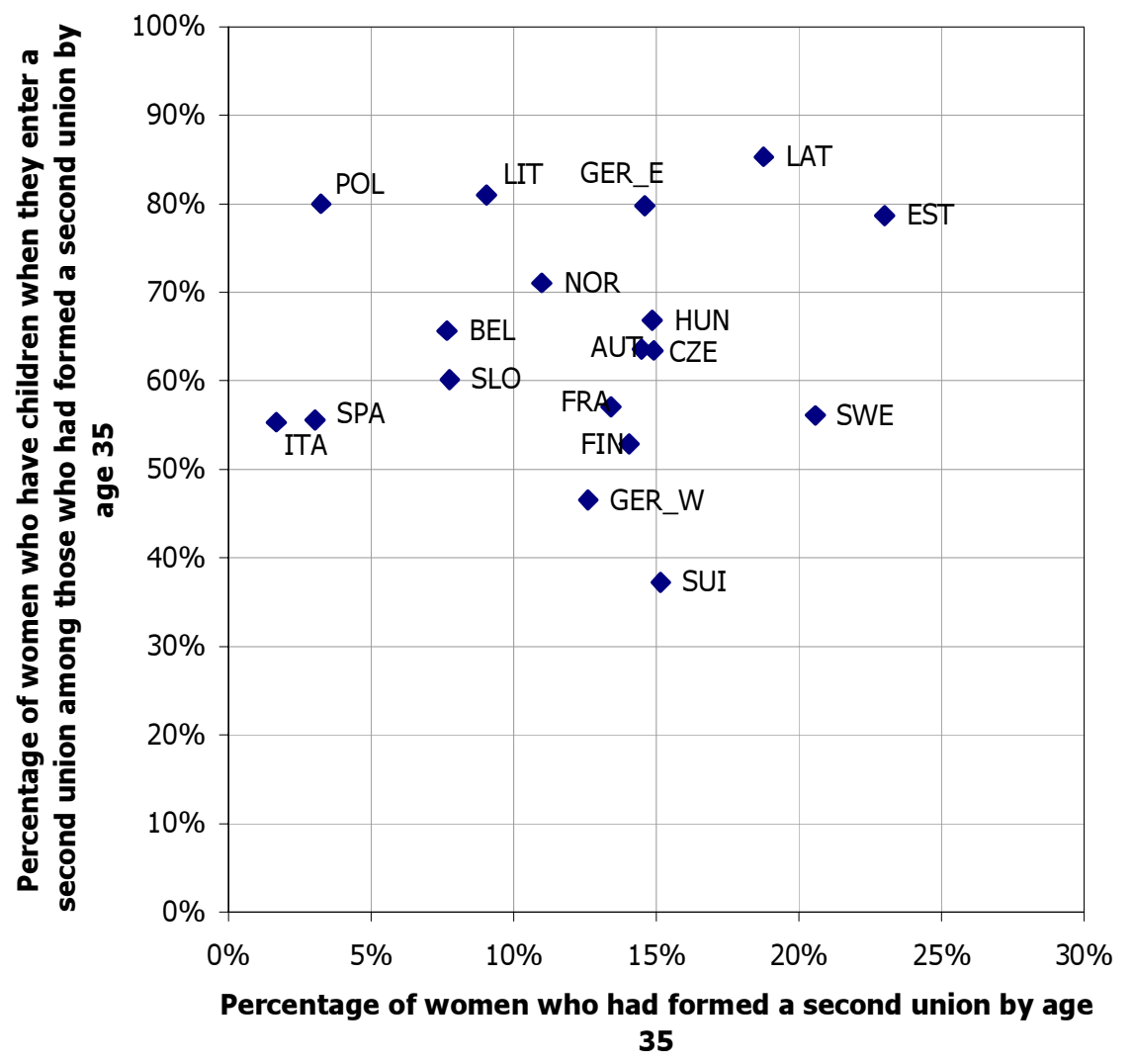

A4: $\quad$ Cohort born in 1952-1955, by age 35 


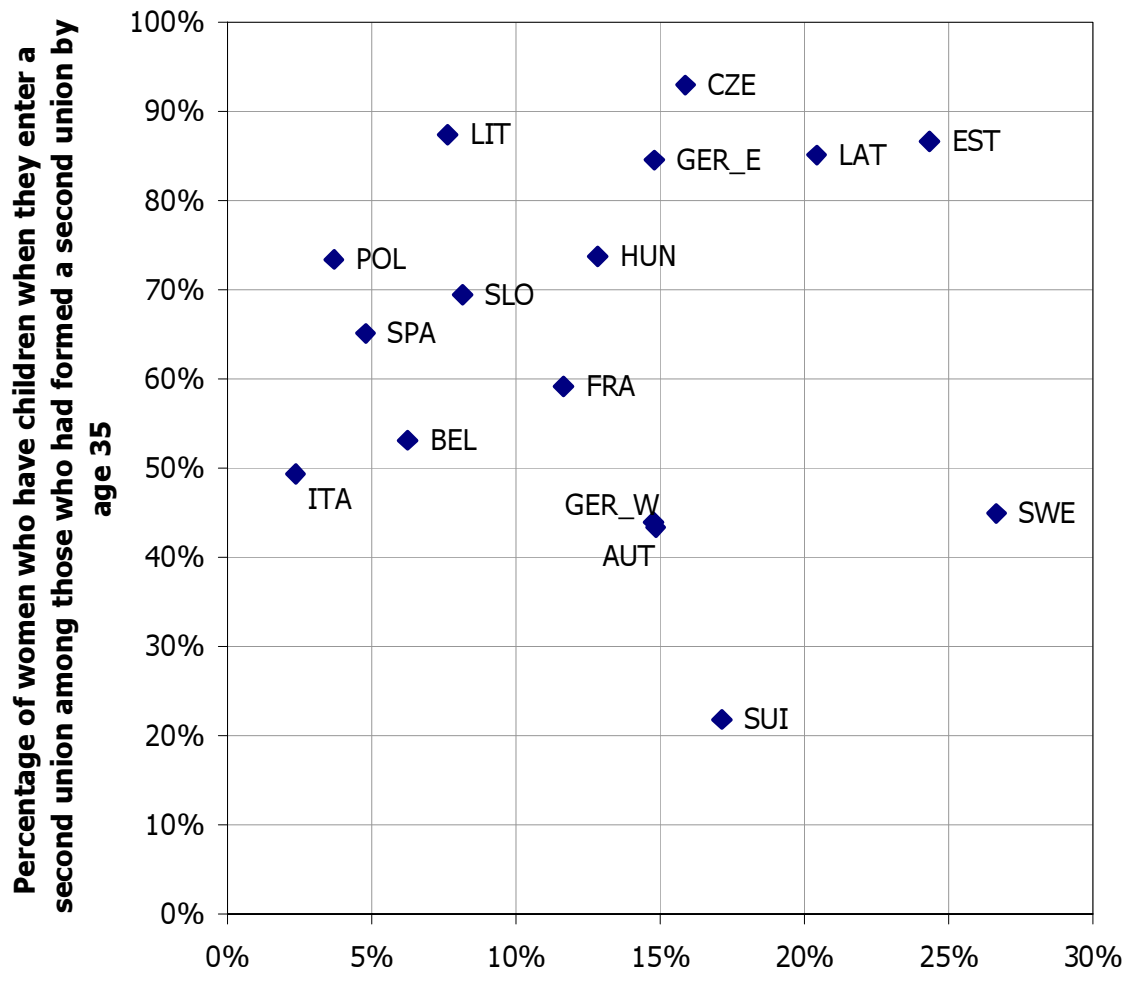

Percentage of women who had formed a second union by age 35

A5:

Cohort born in 1956-1959, by age 35

Notes:

Finland is missing from graphs A3 and A5 because of the earlier time of the survey: the 1956-1959 cohort could not be observed until age 35 and the 1960-1964 cohort was not observed until age 30.

Norway is represented by the 1950 cohort in graphs A1 and A4 and the 1955 cohort in graph A2; not represented in graphs A3 and A5 because of the early time point of the survey.

Sweden is represented by the 1949 cohort in graphs A1 and A4, the 1954 cohort in graphs A2 and A5, and the 1959 cohort in graph A3. 
Figure B: $\quad$ Change from cohort 1952-1955 to 1956-1959 in the country position by women's experience of second unions and the percentage of second unions with pre-union children.

Corresponds to change from plot A4 to plot A5 in Figure A.

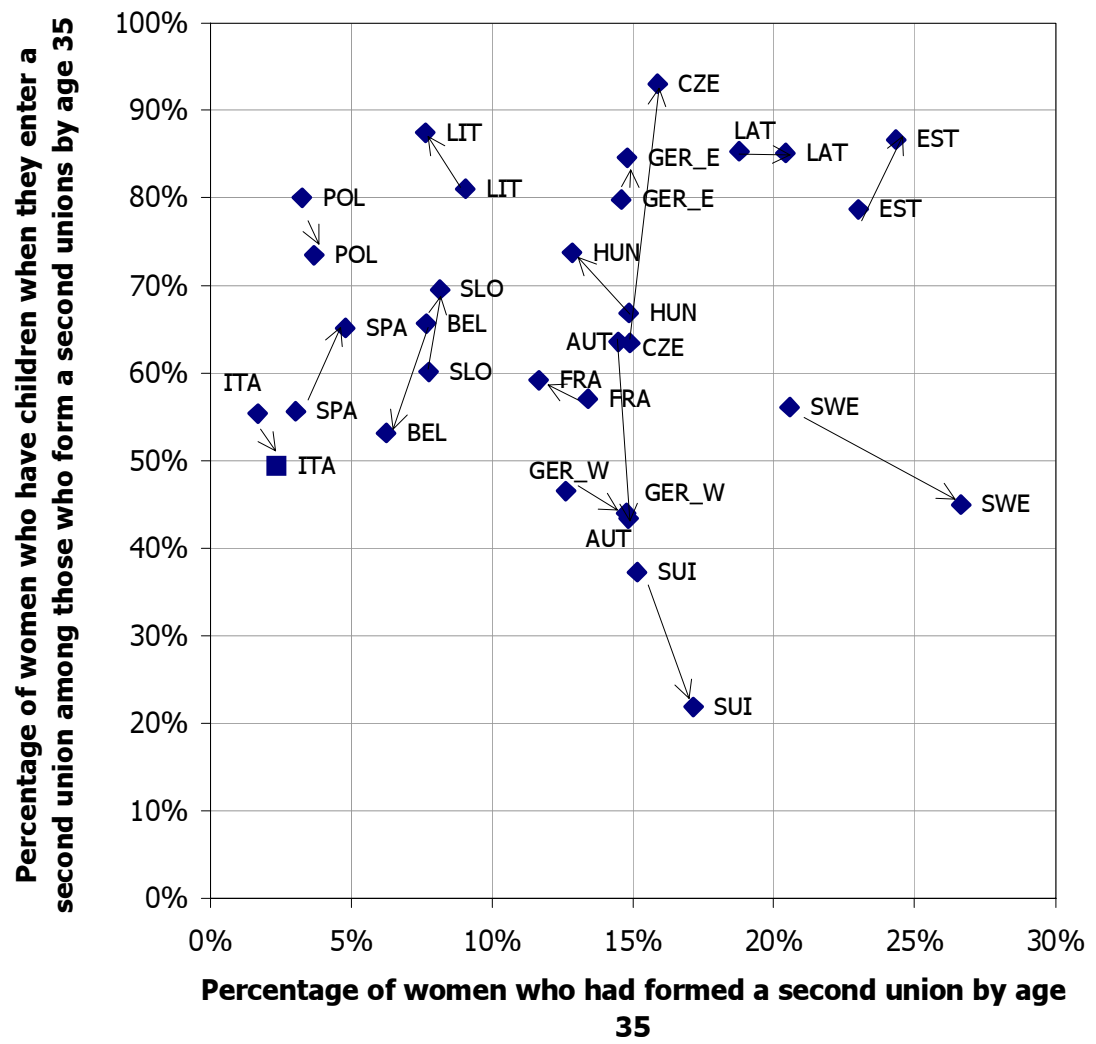

Note: Because of earlier time point of the survey, the 1956-1959 cohort could not be observed until age 35 in Finland, the same applies to the 1955 and 1960 cohorts in Norway. 
Demographic Research - Volume 8, Article 5 